\title{
IMPLEMENTASI KEBIJAKAN PAJAK REKLAME DAN KONTRIBUSINYA TERHADAP PENDAPATAN ASLI DAERAH KABUPATEN DONGGALA
}

\author{
NANANG QOSIM \\ naqo@unisapalu.ac.id \\ (Dosen Fakultas Ekonomi Universitas Alkhairaat) \\ Ovika \\ (Mahasiswa Program Studi Manajemen Fakultas Ekonomi Universitas Alkhairaat)
}

\begin{abstract}
ABSTRAK
Populasi dalam penelitian ini adalah seluruh pegawai pada Kantor Dinas Pendapatan Dan Pengelolaan Keuangan dan Asset Daerah Kabupaten Donggala yang berjumlah 100 orang dan masyarakat yang menjadi wajib pajak reklame. Penelitian ini mengambil seluruh populasi yaitu sampling jenuh (sensus).

Hasil penelitian menunjukkan bahwa implementasi kebijakan Pajak Reklame terhadap peningkatan Pendapatan Asli Daerah pada Dinas Pendapatan, Pengelolaan Keuangan dan Asset Daerah Kabupaten Donggala yang terdiri dari empat indikator yaitu komunikasi (communication), Sumber-sumber (resources), dampak (dispositions) dan Birokrasi (bureaucratic). Dari keempat indikator tersebut masih ada sub indikator yang masih perlu ditingkatkan yaitu sub indikator sarana dan prasarana, pelaksana kebijakan, perilaku pembuat kebijakan, dan kesesuaian pelayanan, namun secara akumulatif responden memberikan tanggapan efektif atau baik. Realisasi pajak reklame dari tahun ke tahun menunjukkan peningkatan dimana pada tahun 2012 dan 2013 relisasi pajak reklame dapat melampai target walaupu n persentasi pencapaiannya menurun pada tahun 2012 sebesar 126,7\% menjadi 104\% pada tahun 2013. Kontribusi pajak reklame terhadap Pendapatan Asli Daerah Kabupaten Donggala masih sangat kurang dengan nilai kontribusi pada tahun 2011 hingga 2013 hanya berkisar rata-rata 0.3\% dari PAD. Ini menunjukkan sektor usaha produktif rakyat tidak berkembang sehingga kegiatan promosi dengan pemasangan reklame rendah. Faktor yang mempengaruhi terhadap realisasi pajak reklame Pendapatan Asli Daerah Pada Dinas Pendapatan Daerah Kabupaten Donggala dapat dijelaskan yaitu : Faktor penghambat dan pendukung realisasi tahun sebelumnya, Pencairah Tagihan Tahun Sebelumnya, Data Potensi dan Estimasi, Penyesuain tarif dan penyempurnaan system pungutan masih perlu ditingkatkan dan menjaadi perhatian bagi implementator. Sedangkan faktor Keadaan Sosial-ekonomi dan kesadaran wajib pajak dan Kebijakan ekonomi dan moneter harus menjadi perhatian khusus Pemerintah Daerah Kabupaten Donggala karena besar kecilnya penerimaan daerah tergantung keadaan ekonomi dan sosial masyarakat maka perlu ada kebijakan - kebijakan ekonomi yang dapat meningkatkan taraf ekonomi dan sosial masyarakat Kabupaten Donggala.
\end{abstract}

Kata Kunci: Implementasi Pajak Reklame, Kebijakan Pajak Reklame dan Pendapatran Asli Daerah.

\section{LATAR BELAKANG}

Salah satu agenda reformasi nasional yang dicanangkan oleh pemerintah adalah yang menyangkut otonomi daerah. Penyelenggaraan pemerintahan dan pembangunan di daerah segenap kemampuan sumber daya dan potensi yang ada di daerah harus dimanfaatkan sebesarbesarnya dengan disertai kebijaksanaan dan langkah-langkah yang tepat guna tujuan pembangunan daerah. Kegiatan penyelenggaraan pemerintah dan pembangunan di daerah tercermin dalam Anggaran Pendapatan dan Belanja Daerah (APBD). Di dalam APBD tersebut bukan hanya anggaran pembangunan saja dapat dilihat, tetapi juga seluruh kegiatan pemerintah dalam satu tahun anggaran yang bersangkutan tergambar dalam bentuk angka-angka sesuai dengan rencana yang telah digariskan oleh pemerintah daerah. Menurut (Rahman, 2019) Dalam organisasi pemerintah maupun swasta pencapaian tujuan ditetapkan melalui sarana dalam bentuk organisasi yang digerakkan oleh sekelompok orang yang berperan aktif sebagai pelaku dalam mencapai tujuan organisasi. Kemampuan pemerintah daerah dalam melaksanakan otonominya dalam bentuk wewenang untuk mengurus dan mengatur rumah tangganya sendiri, tentu saja tidak dapat berjalan secara lancar dan mencapai hasil sebagaimana diharapkan, apabila tidak ditunjang oleh pencapaian dan peningkatan 
pendapatan daerah terutama Pendapatan Asli Daerah Sendiri (PADS) sebagai salah satu tolak ukur otonomi di suatu tempat. Sebagaimana dijelaskan pada Undang-Undang tersebut direvisi menjadi Undang-Undang No. 32 Tahun 2004 tentang Pemerintahan Daerah yang menegaskan kembali pelaksanaan Otonomi Daerah. Otonomi Daerah menurut UU ini diartikan sebagai kewenangan daerah otonom untuk mengatur dan mengurus kepentingan masyarakat setempat menurut prakarsa sendiri berdasarkan aspirasi masyarakat sesuai dengan peraturan perundangundangan.

Dalam rangka pembiayaan pembangunan. Peranan dan potensi sektor perpajakan sangat besar artinya, terutama untuk menunjang keberhasilan pembangunan daerah dan pembangunan nasional. Masalah umum yang dihadapi oleh pemerintah di Indonesia adalah sumber pendapatan daerah. Dimana sumber pendapatan daerah, selain digunakan untuk memenuhi keperluan biaya rutin, Pemerintah juga berkewajiban untuk melaksanakan pembangunan sesuai dengan kemampuan masing-masing daerah. Untuk itu perlu dikehendaki agar memfokuskan perhatian pada usaha pemungutan pajak yang menghasilkan pendapatan yang besar untuk dapat membiayai sebagian besar pengeluaran atas pelayanan yang diberikan kepada masyarakat.

Pajak daerah yang selanjutnya disebut pajak ialah iuran wajib yang dilakukan untuk pribadi atau badan kepada daerah tanpa imbalan langsung yang seimbang, dapat dipaksakan berdasarkan peraturan perundangan yang berlak digunakan untuk penyelenggaraan pemerintah, dan pembangunan daerah. Desentralisasi adalah penyerahan urusan-urusan pemerintah pusat kepada pemerintah daerah yang pada dasrnya menjadi wewenang dan tanggung jawab daerah sepenuhnya (kebijakan, perencanaan, pelaksanaan dan segi-segi pembiayaan). Berkaitan dengan kebijaksanaan Negara dibidang pajak, menurut Suparmoko (2002; 96) pajak disamping sebagai sumber penerimaan Negara yang utama (fungsi budget). Pajak berfungsi sebagai alat mengatur dan mengawasi kegiatan swasta dalam perekonomian (regular), dan pajak sebagai alat anggaran (budgetary), dan pajak digunakan untuk mengumpulkan dana guna membiayai kegiatankegiatan rutin pemerintah. Berbagai upaya atau kebijakan yang ditempuh pemerintah dan disertai pula dengan semakin meningkatnya kesadaran masyarakat dalam memenuhi kewajiban pajaknya, telah mampu meningkatkan penerimaan pajak dari tahun ke tahun.

Pendapatan Asli Daerah, Dana Perimbangan dan Bagi Hasil Pajak Propinsi merupakan jenis penerimaan untuk membiayai pembangunan dan pemerintahan daerah di Kabupaten Donggala. Salah satu jenis pendapatan pajak daerah yang penting peranannya dalam pembiayaan pembangunan daerah pemerintah Kabupaten Donggala adalah melalui penerimaan Pajak Reklame. Pajak reklame merupakan salah satu sumber dari pajak daerah dan retribusi daerah yang merupakan bagian dari sumber pendapatan asli daerah (PAD), seperti diatur di dalam Peraturan Pemerintah No. 58 Tahun 2005 tentang Pengelolaan Keuangan Daerah. Pajak reklame sesuai Perda Kabupaten Donggala Nomor 1 tahun 2011 adalah pajak atas setiap penyelenggaraan reklame yang meliputi objek pajak reklame, subjek pajak reklame, wajib pajak reklame, dasar pengenaan pajak, tarif dan cara penghitungan pajak reklame.

Kebijakan peraturan daerah tesebut bukan hanya untuk dipahami saja, tetapi harus diwujudkan melalui implementasi secara konsisten dan melalui sosialisasi dari pihak yang berkewenangan kepada implementator dengan tujuan untuk meningkatkan pendapatan asli daerah, khususnya Kabupaten Donggala dalam hal ini dinas pendapatan pengelolaan keuangan dan asset daerah, dimana realisasi penerimaan pajak dari pajak reklame jauh dri PAD Kabupaten Donggala dapat dilihat dalam table dibawah ini:

\section{Tabel 1}

\section{Perbandingan Realisasi Pajak Reklame dan Realisasi PAD}

$\begin{array}{lcc}\text { Tahun } & \begin{array}{c}\text { Realisasi Pajak } \\ \text { Reklame }\end{array} & \text { Realisasi PAD } \\ 2011 & \text { Rp 59.926.905,00 } & \text { Rp 18,884,567,534.00 } \\ 2012 & \text { Rp 78.555.322,00 } & \text { Rp 29.989.864.720,68 } \\ & & \\ 2013 & \text { Rp 101.953.410,00 } & \text { Rp 33.314.909.514,39 }\end{array}$

Sumber: DPPKAD Kabupaten Donggala, 2015

Dari tabel diatas menggambarkan kecilnya realisasi pajak reklame dibanding realisasi pendapatan asli daerah (PAD) Permasalahan tersebut berdampak pada pemasukan pajak reklame yang kurang efektif, 
dan sekaligus penulis ingin mengetahui jawaban melalui penelitian dengan judul "Implementasi Kebijakan Pajak Reklame Dan Kontribusinya Terhadap Pendapatan Asli Daerah Kabupaten Donggala."

Berdasarkan uraian latar belakang yang telah dikemukakan sebelumnya, penulis menetapkan beberapa pokok permasalahan sebagai berikut:

1. Bagaimana implementasi kebijakan pajak reklame dan kontribusinya terhadap pendapatan asli daerah Kabupaten Donggala.

2. Faktor yang mempengaruhi implementasi kebijakan pajak reklame dan kontribusinya terhadap pendapatan asli daerah Kabupaten Donggala.

\section{KAJIAN PUSTAKA Kebijakan}

Kebijakan dan implementasi kebijakan merupakan dua hal yang berbeda, namun saling berghubungan satu sama lain. Karena itu sebelum membahas implementasi kebijakan, penulis lebih awal mengkaji kebijakan dengan alasan bahwa perkembangan kedua ilmu tersebut jauh lebih awal berkembang kebijakan. tersebut lebih dipengaruhi para sarjana klasik, oleh karenanya penulis akan mengkaji mengenai kebijakan menurut beberapa ahli sebagai berikut: Yanes (1991:74) mengatakan bahwa: "kebijakan adalah keputusan tetap yang dicirikan oleh konsistensi dan pengembangan tingkah laku diri mereka yang membuat diri mereka mematuhi keputusan tersebut." Wibowo (1994:49) berpendapat bahwa: "kebijakan sebagai sekumpulan rencana kegiatan yang dimaksud untuk memperbaiki efek perbaikan terhadap kondisi sosial ekonomi." Dengan demikian, pada umumnya kebijakan memiliki keputusan dan dilaksanakan secara konsisten dengan tujuan untuk memperbaiki kondisi kehidupan masyarakat pada umumnya, khususnya ekonomi.

Nugroho $(2006 ; 23)$ berpendapat bahwa : " Kebijakan publik adalah pengalokasian nilainilai secara fakta terhadap seluruh anggota masyarakat. Dengan demikian bila pemerintah mengambil keputusan, berarti memiliki sesuatu untuk melakukan sesuatu, maka harus ada tujuannya dan kebijakan Negara itu harus meliputi semua tingkat pemerintah yang dilakukan sematamata merupakan penyataan keinginan pemerintah atau pejabat pemerintah saja. “
Sementara itu, Dunn (2001; 63-64) berpendapat bahwa : " Kebijakan publik merupakan serangkaian pikiran yang kurang lebih berhubungan, termaksud pilihan yang kurang lebih berhubungan, keputusan yang tidak kuat yang dibuat oleh badan atau kantor-kantor pemerintah diformulasikan dalam bidang-bidang issu yaitu arah tindakan aktual atau potensial dari pemerintah, yang didalamnya terkandung kompleks antara kelompok masayrakat."

Winarno $(2002 ; 2)$ mengatakan bahwa: "kebijakan publik adalah apapun yang dipilih oleh pemerintah untuk dilakukan atau tidak dilakukan." Kedua konsep kebijakan tersebut menggambarkan bahwa apapun yang dilakukan atau tidak dilakukan oleh pemerintah, memiliki dampak yang sama terhadap apa yang diinginkan pemerintah.

Dalam suatu kebijakan dikenal adanya proses pembuatan kebijakan, Menurut Dunn (2000; 22) tahap-tahap dalam proses pembuatan kebijakan,sebagai Anderson (1979; 3) mengatakan : publik polices are those policies developed by goverment bodies and officials" (kebijakan negara adalah kebijakan-kebijakan yang dikembangkan oleh badan-badan dan pelajaran-pelajaran pemerintah).

Aplikasi dari pengertian tersebut Anderson (1979; 3) pengertian kebijakan negara adalah:

1. Kebijakan negara selalu mempunyai tujuan tertentu atau merupakan tindakan yang berorientasi pada tujuan.

2. Kebijakan itu berisi tindakan-tindakan atau pola-pola tindakan pejabat-pejabat pemerintah.

3. Kebijakan itu adalah merupakan apa yang benar-benar dilakukan oleh pemerintah, jadi bukan merupakan apa yang pemerintah bermaksud akan melakukan sesuatu atau menyatakan akan melakukan sesuatu.

4. Kebijakan negara biasa bersifat positif artinya merupakan bentuk tindakan pemerintah mengenai suatu masalah tertentu atau bersifat negatif artinya merupakan keputusan pejabat pemerintah untuk tidak melakukan sesuatu.

5. Kebijakan pemerintah setidak-tidaknya dalam arti yang positif didasarkan atas peraturan perundang-undangan Dan bersifat memaksa (otoritatuf). 
Dunn $(2000 ; 85)$ lebih tegas mengatakan proses kebijakan publik memiliki unsur analisis, sebagai berikut :

1. Masalah Kebijakan;

2. Alternatif Kebijakan;

3. Tindakan Kebijakan;

4. Hasil Kebijakan;

5. Kinerja Kebijakan

Kelima unsur ini terangkum dalam proses pembuatan keputusan, mulai dari tahap formulasi rapat sampai pada tahap implementasi dan evaluasi oleh pemerintah dan masyarakat.

Berdasarkan pendapat para pakar kebijakan diatas, dapat disimpulkan bahwa dalam kebijakan publik terdapat beberapa unsur kebijakan. Unsur-unsur tersebut adalah :

1. Lingkungan Kebijakan

Lingkungan Kebijakan adalah keadaan yang melatarbelakangi atau penyebab timbulnya suatu peristiwa, isu atau masalah sehingga memaksa dirumuskannya suatu kebijakan.

2. Pembuat dan pelaksana Kebijakan

Pembuatan dan pelaksana kebijakan adalah orang atau sekelompok orang yang mempunyai pengaruh atau kewenangan dalam pembuatan atau perumusan serta pelaksanaan suatu kebijakan.

3. Kebijakan itu sendiri

Kebijakan itu sendiri yang dimaksud yaitu sejumlah keputusan atau sejumlah pilihan yang berhubungan antara satu dengan yang lainya dalam mencapai tujuan kebijakan itu sendri.

4. Kelompok sasaran

Kelompok Sasaran adalah merupakan target atau sasaran yang ingin dicapai melalui suatu kebijakan yang dapat berupa individu, masyarakat atau organisasi.

Randal B. Ripley dalam H. Afan Gafar (1995; 51) mengemukakan gagasannya bahwa pada dasarnya siklus kebijakan dibagi menjadi 5 (Lima) tahap kegiatan yang terdiri dari agenda setting, proses formulasi, legitimasi tujuan dan program kebijakan, implementasi kebijakan, evaluasi implementasi kebijakan serta keputusan tentang masa depan kebijakan.

Selanjutnya menurut Moeljono (2006 ; 112), kebijakan adalah"kepandaian, kemahiran, atau rangkaian konsep dan asas yang menjadi garis besar dan dasar dari rencana dalam pelaksanaan suatu kegiatan, pekerjaan, kepemimpinan dan cara bertindak".

\section{Implementasi Kebijakan}

Analisis kebijakan tersebut adalah tidak hanya menggabungkan dan memindahkan isi dan metode dari beberapa disiplin, tetapi juga menghasilkan informasi yang relevan dengan kebijakan yang dapat dimanfaatkan untuk memecahkan masalah dan tujuan analisis kebijakan adalah lebih dari sekedar menghasilkan faktor-faktor dan mencari cara untuk menghasilkan informasi mengenai nilai-nilai dan arah tindakan yang lebih baik. Selanjutnya implementasi kebijakan itu mengandung beberapa pengertian, sebagaimana dirumuskan oleh Van Meter dan Van Hom dalam Abdul Wahab (2004; 65) mengemukakan implementasi kebijakan sebagai berikut :

“ Tindakan-tindakan yang dilakukan baik oleh individu-individu/ pejabat-pejabat atau kelompokkelompok, pemerintah atau swasta yang diarahkan pada tercapainya tujuan-tujuan yang telah digariskan dalam keputusan kebijakan. “

Dalam analisis implementasi kebijakan, Udoji (1999; 93) berpendapat bahwa : "pelaksanaan kebijakan adalah sesuatu yang penting, bahkan lebih penting dari pada pembuatan kebijakan. Kebijakan-kebijakan akan sekedar berupa impian atau rencana bagus yang tersimpan rapi, kalau tidak diimplementasikan." Selanjutnya islamy $(1998 ; 102)$ mengemukakan bahwa : "pembuatan kebijakan tidakanya ingin melihat kebijakannya telah dilaksanakan oleh masyarakat, tetapi juga ingin mengetahui seberapa jauh kebijakan tersebut telah memberikan konsekuensi positf dan negative bagi masyarakat." Implementasi kebijakan tersebut dimaknai sebagai jauh lebih penting di dalam aplikasi pada publik bila dibandingkan pembuatan kebijakan, karena pada hakekatnya keluaran kebijakan memiliki subtansi yang ingin dirasakan oleh publik, karenanya dengan melalui implementasi kebijakan dapat memiliki dampak pada masyarakat, baik diharapkan maupun tidak diharapkan.

Darwin (1993; 1) mengatakan bahwa implementasi adalah :

1. Pengadaan sumber daya, baik sumber daya alam, teknologi, manusia dan sumber daya keuangan.

2. Interpretasi terhadap keputusan kebijakan. 
3. Perencanaan (perumusan rencana untuk melaksanakan keputusan kebijakan).

4. Pengorganisasian (pendayagunaan organisasi publik koordinasi kegiatan dan lain-lain).

5. Penyediaan jasa pelayanan.

Dalam pengertian yang lain, Mulyasa (2005; 93) mengatakan bahwa : "implementasi merupakan suatu proses penerapan ide, konsep, kebijakan, atau motivasi suatu tindakan praktis sehingga memberikan dampak baik berupa pengetahuan, keterampilan maupun nilai dan sikap." Hal tersebut memberikan gambaran bahwa implementasi kebijakan dapat dilaksanakan apabila memiliki sumber daya maupun perencanaan sebelum dilakukan keputusan, agar penerapan atau aplikasinya member kontribusi, baik pengetahuan maupun nilai dan sikap dari aspek piskologi.

\section{Pendapatan Asli Daerah}

Pendapatan asli daerah merupakan suatu hal yang sangat urgen untuk dibahas, kerena jalannya suatu roda pembangunan sangat ditentukan oleh beberapa besar keuangan yang dapat dicapai dari sumber kekayaan daaerah, baik itu sumber daya alam maupun sumber daya manusianya. Dalam penjelasan undang-undang nomor 25 tahun 1999 tentang pertimbangan keuangan antara pusat dan daerah, dikatakan bahwa: "yang dimaksud dengan pendapatan asli daerah adalah penerimaan yang diperoleh daerah dari sumber-sumber dalam wilayahnya sendiri, yang dipungut berdasarkan peraturan daerah sesuai dengan peraturan perundang-undangan yang berlaku."

Sumber keuangan daerah dalam kaitannya dengan berbagai asas pemerintah didaerah diatur dalam pasal 76 nomor 22 tahun 1999 tentang pemerintahan daerah. sumbersumber pendapatan asli daerah terdiri atas :

1. Pendapatan asli daerah, terdiri dari:

a. Hasil pajak daerah

b. Hasil retribusi daerah

c. Hasil perusahaan milik daerah dan hasil pengelolaan kekayaan daerah yang dipisahkan, dan

d. Pendapatan hasil daaerah yang sah.

2. Dana pertimbangan

3. Pinjaman daerah

4. Lain-lain pendapatan yang sah.

Sehubungan dengan ketentuan tersebut diatas, meka jenis-jenis sumber pandapatan asli daerah yang dapat dipungut oleh daerah adalah menuju otonomi daerah di Kabupaten Donggala, maka pengelolaan peningkatan pendapatan asli daerah perlu semakin diintensifkan, agar tercapai keseimbangan antara pelaksana tugas-tugas pemerintahan dan pembangunan serta dapat mendukung terciptanya aparat yang bersih dan bertanggung jawab. Pandapatan asli daerah merupakan pendapatan yang diperoleh pemerintah daerah dari berbagai sumber yang ditetapkan berdasarkan peraturan perundang-undangan untuk membiayai pelaksanaan pemerintah didaerah. Kebijakan keuangan daerah berhubungan erat dengan kebijakan Negara. Hubungan tersebut tidak hanya bersifat keuangan, tetapi juga berhubungan dengan faktor-faktor lain yang dapat dilihat dari tiga segi, yaitu penyelenggaraan pemerintah didaerah, berkenaan dengan hubungan itulah, maka perlu perancanaan.

Menurut penulis, pendapatan asli daerah merupakan modal dasar bagi setiap daerah dalam melaksanakan kegiatan pemerintahan dan pembangunan, dan sekaligus merupakan suatu bukti terhadap tinggiya kesadaran masyarakat dalam mendukung pemerintahan dalam menggali sumber-sumber pendapatan asli daerah.

\section{Pajak reklame}

Berdasarkan peraturan daerah kebupaten donggala nomor 1 tahun 2011 tentang pajak daerah, dijelaskan bahwa pajak reklame adalah pajak atas penyelenggaraan reklame, sedangkan reklame sendiri itu adalah benda, alat, perbuatan atau media yang bentuk corak ragamnya dirancang untuk tujuan komersial memperkenalkan,menganjurkan, mempromosikan atau menarik perhatian umum terhadap barang, jasa, orang yang dapat dilihat, dibaca, didengar, dirasakan dan/atau dinikmati oleh umum. Dengan berkembangnya teknologi, semakin banyak pula perusahaan yang memproduksi suatu produk atau barang, hal ini perlu disebarluaskan agar masyarakat lebih mengenal dan memakai barang yang diproduksi oleh suatu perusahaan tesebut. Karena itu perlu adanya suatu sasaran untuk memproduksi sebuah produk, diantaranya adalah pemasangan papan reklame di kebupaten donggala, mengingat pajak reklame merupakan salah satu penerimaan daerah yang potensial, maka pemerintah daerah berusaha untuk mengoptimalkan pendapatan kembali reklamereklame yang ada.

Pajak mempunyai peranan yang sangat penting dalam kehidupan bernegara, khususnya 
didalam pelaksanaan pembagunan. Karena pajak merupakan sumber pendapatan Negara untuk membiayai semua pengeluaran, termaksud pengeluaran pembangunan. Bedasarkan hal tersebut, maka pajak mempunyai beberapa fungsi, yaitu :

1. Fungsi anggaran (budgetair)

Sebagai sumber pendapatan Negara, pajak berfungsi untuk membiayai pangeluaranpengeluaran Negara. Untuk menjalankan tugas-tugas rutin Negara dan melaksanakan pembangunan, Negara membutuhkan biaya. Biaya ini dapat diperoleh dari penerimaan pajak. Dewasa ini pajak digunakan untuk pembayaran rutin seperti belanja pegawai, belanja barang, pemeliharaan dan lain sebagainya. Untuk pembiayaan pembangunan, uang yang dikeluarkan dari tabungan pemerintah, yakni penerimaan dalam negeri dikurangi pengeluaran rutin. Tabungan pemerintah ini dari tahun ke tahun harus ditingkatkan sesuai kebutuhan pembiayaan pembangunan yang semakin meningkat dan ini terutama diharapkan dari sektor pajak.

2. Fungsi mengatur (regulerend)

Pemerintah biasa mengatur pertumbuhan ekonomi melalui kebijaksaan pajak. Dengan fungsi mengatur, pajak biasa digunakan sebagai alat untuk mencapai tujuan, contohnya dalam rangka menggiring penanaman modal dalam negeri maupun luar negeri, diberikan bernbagai macam fasilitas keringanan pajak. Dalam rangka melindugi produksi dalam negeri, pemerintah biaya masuk yang tinggi untuk produk luar negri.

3. Fungsi stabilitas

Dengan adanya pajak, pemerintah memiliki dana untk menjalankan kebijakn yang berhubungan dangan stabilitas harga, sehingga inflasi dapat dikendalikan. Hal ini biasa dilakukan antara lain dengan jalan mengatur peredaran uang di masyarakat, pemungutan pajak, panggunaan pajak yang efektif dan efisien.

4. Fungsi redistribusi pendapatan

Pajak yang sudah dipungut oleh Negara akan digunakan untuk membiayai semua kepentingan umum, termaksud juga membiayai pembangunan sehingga dapat membuka kesempatan kerja yang pada akhinya akan dapat meningkatkan pendapatan masyarakat.

\section{Kerangka Pemikiran}

Berbagai pemikiran tentang model implementasi kebijakan, yang bertujuan untuk mengukur keberhasilan keluaran-keluaran, kebijakan dari aspek penerapan dan tindakan oleh impementator, sehingga dapat dinilai keberhasilan atau kurang berhasil. Karena untuk mengukur keberhasilan tersebut penulis merelevansikan variabel komunikasi, sumber daya, disposisi dan struktur birokrasi yang dibangun oleh Edward III dalam winarno $(2002$; 152) mengenai penerapan implementasi kebijakan pajak reklame tersebut dapat pula dimaknai dampak dari peningkatan pemasukan pendapatan asli daerah pada dinas pengelolaan keuangan dan asset daerah kebupaten donggala dengan ukuran target dan realisasi, kesadaran masyarakat, wajib pajak, kesesuaian system pungutan suriadinata $(1994 ; 103)$ untuk lebih jelasnya dapat dilihat dalam kerangka pikir betikut ini :

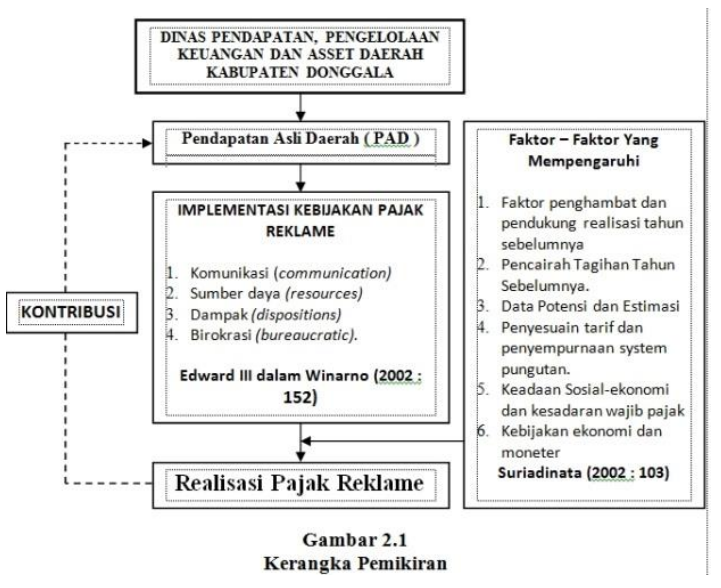

\section{Defenisi Operasional Variabel}

Dalam proses penelitian ini, penulis menyajikan defenisi oprasional variabel independen dan variable dependen yang satu sama lain saling mempengaruhi. Adapun kedua veriabel tersebut dapat dijelaskan sebagai berikut :

1. Variabel Independen (bebas) atau variable yang mempengaruhi yaitu implementasi kebijakan reklame adalah suatu proses penerapan kebijakan terhadap implementator dengan factor-faktor komunikasi, resource, disposisi dan struktur birokrasi. Perameter ini diukur dari :

- Komunikasi;

- Sumber daya;

- Dampak;

- $\quad$ Struktur birokrasi. 
2. Variable Dependen (terikat) atau veriabel yang dipengaruhi yaitu kontribusi pajak reklame terhadap penerimaan pendapatan asli daerah, Analisis KontribusiMenurut Widodo (1990:20) dalam Dasril, Henry dan Hessel (2004; 22) Analisis kontribusi yaitu suatu alat analisis yang digunakan untuk mengetahui seberapa besar kontribusi dapat disumbangkan dari penerimaan terhadap anggaran. Penggunaan analisis dapat diketahuiperan pajak daerah dan retribusi daerah dalam kontribusi terhadap PAD. Sedang kan menurut Menurut Kamus ekonomi (T Guritno 1997; 76) kontribusi adalah sesuatu yang diberikan bersama-sama dengan pihak lain untuk tujuan biaya atau kerugian tertentu atau bersama. Sehingga kontribusi yang dimaksud dapat diartikan sebagai sumbangan yang diberikan oleh pendapatan pajak atas kendaraan bermotor terhadap pendapatan asli daerah. untuk mengetahui kontribusi pajak atas kendaraan bermotor terhadap Pendapatan Asli Daerah, digunakan rumus sebagai berikut :

Kontribusi Pajak Reklame $=\frac{\text { Realisasi Pajak Reklame }}{\text { Realisasi PAD }} \times 100 \%$

Tabel 2

Klasifikasi Kriteria Kontribusi

Persentase

$0 \%-10 \%$

$10,10 \%-20 \%$

$20,10 \%-30 \%$

$30,10 \%-40 \%$

$40,10 \%-50 \%$

Diatas 50\%

Sumber : Depdagri,

Sangat Baik

Sangat Kurang

Kurang

Sedang

Cukup Baik

Baik

No.690.900.327 (Velayati Dkk, 2013)

\section{Populasi dan Sampel}

Populasi adalah seluruh penduduk yang dimaksudkan untuk diselidiki, menurut Sutrisno Hadi (1997; 220) populasi adalah "Sejumlah penduduk atau individu yang paling sedikit mempunyai satu sifat yang sama". Berdasarkan pada pengertian tersebut yang menjadi populasi dalam penelitian ini adalah semua Pegawai
Negeri Sipil yang bekerja pada Dinas Pendapatan Dan Pengelolaan Keuangan dan Asset Daerah Kabupaten Donggala yang berjumlah 100 orang dan masyarakat yang menjadi wajib pajak reklame.

Pengertian sampel ialah jumlah atau karasteristik dari populasi, yang dianggap dapat memahami dan memberikan data yang diperlukan oleh peneliti sesuai objek penelitian Untuk efesiensi penelitian penarikan sampel dilakukan dengan teknik purposive sampling. Menurut Faisal (2001; 67) purposive sampling adalah "penarikan secara sengaja oleh penulis didasarkan atas kriteria atau pertimbangan-pertimbangan tertentu".

Adapun dasar penentuan jumlah sampel mengacu pada pendapat Arikunto (2006; 107) yang menyebutkan bahwa :

Apabila dalam suatu penelitian karakteristik yang ditetapkan sebagai subjek kurang dari 100 maka ketentuan penelitian harus diambil secara keseluruhan, sehingga penelitiannya merupakan penelitian populasi. Selanjutnya jika subjeknya besar atau lebih dari 100 maka dapat diambil 10$15 \%$ atau $20-25 \%$ atau lebih.

Melihat populasi yang begitu besar, maka dalam hal ini penulis menggunakan sampel sebagai wakil dari populasi tersebut. Adapun teknik penarikan sampel dengan menggunakan teknik purposive sampling yaitu memilih dengan sengaja responden yang dapat memberikan data akurat dan dapat dipertanggung jawabkan berjumlah 37 orang dengan rincian sebagai berikut :

- Kepala Bidang Pendapatan:1 orang

- Kasi Penetapan Pajak dan Retribusi/Staf: 5 orang

- Kasi Dana Perimbangan dan dana lain-lain pendapatan yang sah Dan Staf: 5 orang

- Kasi Keberatan dan Tindak Lanjut/Staff:5 orang

- Masyarakat wajib pajak reklame:21 orang

Jumlah 37 Orang

Untuk mendapatkan data yang akurat maka penulis menggunakan informan kunci yaitu Kepala Dinas Pendapatan Pengelolaan Keuangan dan Asset Daerah Kabupaten Donggala.

\section{Teknik Pengumpulan Data}

Sesuai dengan masalah yang diteliti, maka peneliti menggunakan empat teknik pengumpulan data, sebagai berikut :

1. Pengamatan (observation) 
Karlinger dalam Sugiono (2006; 222) berpendapat bahwa : "mengobservasi adalah suatu istilah umum artinya semua bentuk penerimaan data yang dilakukan dengan cara menekan kejadian, menghtungnya, mengukurnya dan mencatatnya."

2. Wawancara (interview)

Esterberg dalam Sugiono (2006; 72) mengatakan bahwa ; "wawamcara adalah merupakan pertemuan dua orang untuk bertukar informasi dan ide melalui tanya jawab sehingga dapat dikonstruksikan makna dalam suatu topic tertentu."

3. Kuesioner (Kuisioner)

Menurut Bovuch dalam Black and Champion (2001; 335) bahwa : "kuesioner merupakan teknik pengumpulan data yang menggunakan metode penyebaran daftar pertanyaan pada responden tanpa terganggu privasi oleh karena pengisian."

4. Dokumentasi

Pengumpulan data melalui dokumentasi dilakukan dengan cara membaca, mencatat atau mengcopy dokumen-dokumen, arsip - arsip maupun laporan data- data lain yang terkait dengan permasalahan penelitian. Teknik ini digunakan dengan maksud agar data sekunder yang erat kaitannya dengan fokus penelitian ini dapat menjadi bahan kelengkapan yang mendukung analisis data penelitian ini. Selain itu, akan mencantumkan foto /gambar yang berkaitan dengan masalah penelitian.

\section{Teknik Analisis Data}

Dalam penelitian ini peneliti melakukan analisis deskriptif untuk menggambarkan deskripsi objek yang diteliti, analisis deskriptif ini hanya digunakan untuk mengolah dan menyajikan data tanpa mengambil keputusan untuk dalam penelitian ini. Analisis deskriptif digunakan untuk mendeskripsikan atau memberi gambaran terhadap obyek yang diteliti melalui data sampel atau populasi sebagaimana adanya, tanpa melakukan analisis dan membuat kesimpulan yang berlaku untuk umum (Sugiyono, 2006; 29).

Teknik analisis data yang digunakan pada penelitian ini adalah analisis deskriptif kualitatif, dengan menguraikan seluruh data dan fakta yang berhasil dikumpulkan dalam bentuk narasi dan argumentasi yang berlandaskan pada data lapangan yang telah diperoleh dengan menggunakan tabel Frekuensi dan Presentase. Teknik ini bertujuan untuk menggambarkan fenomena tertentu secara lebih terperinci tentang implementasi kebijakan pajak reklame terhadap peningkatan Pendapatan Asli Daerah pada Dinas Pendapatan Dan Pengelolaan Keuangan dan Aset Daerah Kabupaten Donggala

Singarimbun (2006; 35) berpendapat bahwa analisis data adalah proses penyederhanaan data dalam bentuk yang lebih mudah di baca dan di interprestasikan. Data tersebut dianalisis dalam kerangka hubungan antara variabel penelitian. Untuk mengukur nilai dari variabel digunakan rating scale.

Sugiyono (2003), menyatakan bahwa Skala Likert digunakan untuk mengukur sikap, pendapat dan persepsi seseorang atau sekelompok orang tentang fenomena sosial. Dalam penelitian, fenomena sosial ini telah ditetapkan oleh peneliti, yang selanjutnya disebut sebagai variabel penelitian. Dengan Skala Likert, maka variabel yang akan diukur dijabarkan menjadi indikator variabel. Kemudian indikator tersebut dijadikan titik tolak untuk menyusun item-item instrumen yang dapat berupa pernyataan atau pertanyaan.

Untuk keperluan analisis, maka jawaban dalam kuisioner tersebut sebagai berikut.

1. Jawaban sangat setuju dengan skor 5

2. Jawaban setuju dengan skor 4

3. Jawaban kurang setuju dengan skor 3

4. Jawaban tidak setuju dengan skor 2

5. Jawaban sangat tidak setuju dengan skor 1

\section{HASIL DAN PEMBAHASAN}

\subsubsection{Faktor-Faktor Implementasi Kebijakan Pajak Reklame Kabupaten Donggala}

Pelayanan publik yang diberikan oleh aparat pemerintah dalam suatu birokrasi pemerintahan sudah menjadi rahasia umum bahwa kualitasnya rendah. Namun hal ini tidak menjadikan alasan utama untuk tetap pesimistik atas perubahan yang mungkin terjadi dalam paradigma pelayanan yang selama ini menempatkan aparat dengan birokrasinya pada posisi yang harus dilayani, tetapi harus berubah kepada paradigma yang menempatkan pengguna jasa (konsumen) pada posisi yang lebih tinggi.

Upaya pergeseran paradigma yang dimaksud diatas, secara ideal mesti dimulai dari kemauan (goodwill) pemerintah, melalui penyempurnaan kebijakan-kebijakan di bidang pelayanan. Oleh karena itu orientasi pelayanan harus berubah dari sekedar memenuhi kebutuhan pengguna jasa kearah pelayanan yang memuaskan 
pengguna jasa disertai dengan perilaku pelayanan secara tertulis. Untuk dapat mencapai taraf pelayanan seperti ini, pelayan atau aparat tidak hanya dituntut harus menguasai teknik pelayanan (IQ) tetapi juga harus memiliki kesadaran emosional (EQ), agar tercapai pelayanan yang memuaskan dan sepenuh hati sesuai dengan standard pelayanan yang berkualitas.

Pelayanan yang berkualitas merupakan hal yang harus dipenuhi oleh setiap organisasi yang menawarkan/menjual jasanya kepada publik. Telah dikemukakan pada bagian terdahulu bahwa suatu pelayanan dikatakan berkualitas jika mampu memenuhi preferensi konsumennya. Dengan demikian, kepuasan pelanggan merupakan determinan kunci untuk bias mencapai suatu pelayanan yang berkualitas.

Dalam kondisi persaingan sempurna di mana masyarakat mampu memilih di antara berbagai alternatif pelayanan yang ditawarkan, kepuasan pengguna jasa mau tidak mau harus dipenuhi. Untuk dapat memuaskan pengguna jasa melalui pelayanan yang diberikan maka setiap organisasi perlu mengetahui sejauh mana tingkat kepuasan konsumen terhadap pelayanan yang diberikan, sebab dari hal inilah setiap organisasi akan dapat melakukan identifikasi strategi-strategi bagi perbaikan kinerjanya.

Kepuasan masyarakat atau pengguna jasa juga sangat ditentukan kualitas dari yang memberikan pelayanan. Dinas Pendapatan, Pengelola Keuangan dan Aset Kabupaten Donggala sebagai organisasi pemerintah yang bergerak dalam bidang Peternakan dituntut sebagai ujung tombak dalam meningkatkan pembangunan khususnya dalam bidang keuangan. Olehnya itu kemampuan pegawai dalam memberikan pelayanan merupakan tolok ukur atas keberhasilan Dinas Pendapatan, Pengelola Keuangan dan Aset Kabupaten Donggala dalam meningkatkan mutu pelayanan sehingga dapat memberikan rasa puas kepada masyarakat.

Pelayanan terhadap publik terdiri dari berbagai dimensi yang cukup kompleks, sehingga pemecahan masalah terhadap kinerja pelayanan publik tersebut membutuhkan sebuah proses dan cara-cara yang tidak mudah dan simpel, Hal ini mengharuskan kita untuk selalu melihat permasalahan yang muncul dengan berbagai dimensi, dan jangan hanya dilihat dari satu dimensi semata saja. Dalam konteks ini Dinas Pendapatan, Pengelola Keuangan dan Aset Kabupaten Donggala yang merupakan organisasi penyedia pelayanan di bidang keuangan dengan tugas teknis dan administratifnya. Dengan demikian Dinas Pendapatan, Pengelola Keuangan dan Aset Kabupaten Donggala harus tetap melakukan langkah-langkah perbaikan disegala aspek kegiatannya, mengingat otonomi daerah serta kesiapannya menjelang era perdagangan bebas diberlakukan.

Konsekwensi logis bagi Dinas Pendapatan, Pengelola Keuangan dan Aset Kabupaten Donggala selaku organisasi pelayanan publik adalah menempatkan klien atau masyarakat pengguna jasa sebagai faktor terpenting dalam pelaksanaan tugas. Telah disinggung pada bagian kerangka teori, bahwa kontrol oleh publik sebagai pengguna jasa dapat digunakan sebagai cara untuk penilaian terhadap baik atau tidaknya kinerja pelayanan yang diberikan oleh organisasi pelayanan publik tersebut. Hal ini amat erat kaitannya dengan kepuasan pelanggan terhadap kinerja pelayanan Dinas Pendapatan, Pengelola Keuangan dan Aset Kabupaten Donggala.

Analisis pengukuran indeks implementasi dari kebijakan dan kualitas pelayanan dilakukan atas dasar standar nilai rata-rata dari setiap kategori yang dicantumkan. Butir-butir instrument implementasi dari sebuah kebijakan yang diterapkan dapat dilihat dari komunikasi, sumber-sumber, kecenderungan dan birokrasi pemerintah itu sendiri. Sementara itu pelayanan yang diberikan sebagai wujud dari implementasi sebuah kebijakan dapat dilihat dari kesederhanaan, kejelasan dan kepastian, keadilan yang merata, dan ketepatan waktu dalam memberikan pelayanan

\section{a. Komunikasi}

Komunikasi merupakan suatu proses sosial yang sangat mendasar dan vital dalam kehidupan manusia. Dikatakan mendasar karena setiap masyarakat berkeinginan mempertahankan suatu persetujuan mengenai aturan sosial melalui komunikasi. Dikatakan vital karena setiap individu memiliki kemampaun untuk berkomunikasi degan individu lainnya.

Dalam ruang lingkup yang lebih rinci, komunikasi menggambarkan bagaimana seseorang menyampaikan sesuatu lewat bahasa dan simbol-simbol tertentu kepada orang lain, sehingga tujuan atau sasaran yang telah ditetapkan akan dapat tercapai. Karena itu jika kita berkomunikasi, maka kita memiliki beberapa kesamaan bahasa atau kesamaan arti dari simbolsimbol yang digunakan dalam berkomunikasi. 
Dari pengertian komunikasi yang telah dikemukakan, maka jelas bahwa komunikasi antar manusia hanya bisa terjadi, jika seseorang yang menyampaikan pesan kepada orang lain dengan tujuan tertentu, artinya komunikasi hanya terjadi kalau didukung oleh adanya sumber, pesan, media, penerima dan efek. Unsur-unsur ini bisa juga disebut komponen atau elemen dalam komunikasi.

Sebuah keputusan atau kebijakan untuk dapat mencapai hasil yang maksimal, maka harus pula disosialisasikan kepada masyarakat. Hal ini dimaksudkan agar masyarakat memahami dan mengerti dan mematuhi segala kebijakan yang telah ditetapkan oleh pemerintah. Selain itu dengan adanya komunikasi maka keputusan atau kebijakan pemerintah tersebut akan diketahui tingkat keberhasilannya, sehingga dapat diketahui pula kegunaannya. Demikian juga Dinas Pendapatan, Pengelola Keuangan dan Aset Kabupaten Donggala, dalam upaya meningkatkan efektifitas pelayanan, maka berbagai kebijakan telah dilakukan sebagai wujud dari pengejawentahan visi dan misi Kabuapeten Donggala umumnya dan Dinas Pendapatan, Pengelola Keuangan dan Aset Kabupaten Donggalapada khususnya.

Untuk mengetahui tingkat keberhasilan kebijakan tersebut, maka kebijakan yang telah ditetapkan dalam upaya peningkatan pelayanan harus diketahui oleh publik sebagai pengguna jasa. Olehnya itu untuk memberikan pemahaman dan pengertian tentang kebijakan yang telah ditetapkan, maka pihak Dinas Pendapatan, Pengelola Keuangan dan Aset Kabupaten Donggala melaksanakan sosialisasi kebijakan tersebut. Hasil penelitian menunjukkan bahwa pelaksanaan sosialisasi tersebut mendapat sambutan yang baik dari masyarakat, karena dengan adanya sosialisasi, maka masyarakat luas sebagai pengguna jasa mengetahui arah kebijakan yang ditetapkan oleh Dinas Pendapatan, Pengelola Keuangan dan Aset Kabupaten Donggala tersebut, dan untuk lebih jelasnya hasil tanggapan responden terhadap item tersebut, maka dapat disimak pada tabel berikut ini:

Tabel 3

Tanggapan Responden Tentang Sosialisasi Kebijakan

\begin{tabular}{|c|l|c|c|}
\hline No. & \multicolumn{1}{|c|}{$\begin{array}{c}\text { Klasifikasi } \\
\text { Jawaban }\end{array}$} & Frekuensi & $\begin{array}{c}\text { Persentase } \\
(\mathbf{\%})\end{array}$ \\
\hline 1 & Sangat Setuju & 27 & 73,0 \\
\hline 2 & Setuju & 9 & 24,3 \\
\hline
\end{tabular}

\begin{tabular}{|c|l|c|c|}
3 & Kurang Setuju & 1 & 2,7 \\
\hline 4 & Tidak Setuju & 0 & 0 \\
\hline 5 & Sangat Tidak Setuju & 0 & 0 \\
\hline \multicolumn{2}{|c|}{ Total } & $\mathbf{3 7}$ & $\mathbf{1 0 0}$ \\
\hline
\end{tabular}

Sumber : Hasil Olahan Data Primer, 2015

Tabel di atas menunjukkan bahwa 27 orang atau $73,0 \%$ memberikan pernyataan sangat baik terhadap sosialisasi kebijakan dalam upaya meminimalisir hambatan, 9 orang atau $24,3 \%$ memberikan pernyataan baik, dan 1 orang responden atau $2,7 \%$ memberikan pernyataan kurang baik . Hasil penelitian menunjukkan bahwa sosialisasi kebijakan dalam upaya meminimalisir hambatan telah dilaksanakan dengan baik.

Mengacu pada tanggapan responden, maka untuk mengoptimalkan kebijakan Dinas Pendapatan, Pengelola Keuangan dan Aset Kabupaten Donggala, kebijakan tersebut telah disosialisasikan secara kontinyu sesuai dengan waktu yang telah ditetapkan. Hal ini dimaksudkan agar masyarakat dapat memahami dan mengetahui tentang kebijakan yang telah ditetapkan tersebut. Seperti yang dikemukakan oleh Fitriani Kepala Sub Bagian Perencanaan dan Program pada Dinas Pendapatan, Pengelola Keuangan dan Aset Kabupaten Donggala.

Kebijakan yang telah ditetapkan oleh Dinas Pendapatan, Pengelola Keuangan dan Aset Kabupaten Donggala sebenarnya merupakan acuan atau pedoman dalam pelaksanaan kegiatan. Olehnya itu agar pengelola keuangan di setiap SKPD mengetahui kebijakan tersebut, maka pihak Dinas Pendapatan, Pengelola Keuangan dan Aset Kabupaten Donggala secara kontinyu melaksanakan sosialisasi kebijakan melalui pendidikan dan pelatihan maupunpenyuluhan. (Hasil wawancara, 6 Januari 2015)

Menyimak dari tanggapan responden adan informan di atas, dapatlah dikemukakan bahwa sosialisasi kebijakan yang telah ditetapkan harus dilaksanakan secara kontinyu. Hal ini merupakan wahana Dinas Pendapatan, Pengelola Keuangan dan Aset Kabupaten Donggala dalam menyelenggarakan segala kegiatan sesuai dengan tugas pokok dan fungsinya.

Selanjutnya dalam mengimplementasikan kebijakan sebagaimana yang diharapkan, maka pelaku/pelaksana kebijakan, harus menerima petunjuk-petunjuk pelaksanaan (juklak) yang jelas untuk dipahami agar tidak terjadi implementasi yang salah. Hasil 
penelitian menunjukkan bahwa dari 37 responden, 33 orang responden memberikan tanggapan sangat Setuju atau sekitar $89,2 \%$. Sementara itu yang memberikan tanggapan Setuju terhadap sikap pelaku/pelaksana kebijakan dalam menerima petunjuk pelaksanaan berjumlah 4 orang responden atau sebesar 10,8\%. Untuk lebih jelasnya dapat disimak dalam tabel berikut ini:

Tabel 4

Tanggapan Responden Tentang Sikap Pelaku/Pelaksana Kebijakan Menerima Petunjuk-Petunjuk Pelaksanaan (JUKLAK)

\begin{tabular}{|c|l|c|c|}
\hline No. & $\begin{array}{l}\text { Klasifikasi } \\
\text { Jawaban }\end{array}$ & Frekuensi & $\begin{array}{c}\text { Persentase } \\
(\boldsymbol{\%})\end{array}$ \\
\hline 1 & Sangat Setuju & 33 & 89,2 \\
\hline 2 & Setuju & 4 & 10,8 \\
\hline 3 & $\begin{array}{l}\text { Kurang } \\
\text { Setuju }\end{array}$ & 0 & 0 \\
\hline 4 & Tidak Setuju & 0 & 0 \\
\hline 5 & $\begin{array}{l}\text { Sangat Tidak } \\
\text { Setuju }\end{array}$ & 0 & 0 \\
\hline \multicolumn{2}{|c|}{ Total } & $\mathbf{3 7}$ & $\mathbf{1 0 0}$ \\
\hline
\end{tabular}

Sumber : Hasil Olahan Data Primer, 2015

Berdasarkan hasil pengolahan data di atas, menunjukan bahwa responden memberikan pernyataan baik terhadap sikap pelaku/pelaksana kebijakan dalam menerima petunjuk pelaksanaan yang jelas untuk dipahami agar tidak terjadi implementasi yang salah. Pernyataan responden tentang pelaku/pelaksana kebijakan, harus menerima petunjuk-petunjuk pelaksanaan (juklak) yang jelas untuk dipahami agar tidak terjadi implementasi yang salah, dan hal tersebut merupakan kewajiban yang harus diketahui oleh pelaku kebijakan, agar kebijakan tersebut dapat efektif dan efisien.

Ajis Sekretaris Dinas Pendapatan, Pengelola Keuangan dan Aset Kabupaten Donggala, mengemukakan:

Dalam mengimplementasikan kebijakan sebagaimana yang diharapkan, maka pelaku/pelaksana kebijakan, harus menerima petunjuk-petunjuk pelaksanaan (juklak) yang jelas untuk dipahami agar tidak terjadi implementasi yang salah. Dengan adanya petunjuk tersebut, maka pemahaman pengelola keuangan di setiap SKPD dan pelaku kebijakan dalam mengimplementasikan kebijakan tersebut tepat sasaran dan tepat penggunaan. (Hasil wawancara, 6 Januari 2015)

Sebuah kebijakan dapat dikatakan efektif apabila dalam kebijakan tersebut tidak merugikan masyarakat, efektif dan efisien, dengan harapan bahwa kebijakan mampu meminimalisir berbagai konflik yang terjadi baik pada saat ini maupun yang akan datang. Olehnya itu apabila implementasi kebijakan ingin berlangsung efektif, maka perintah-perintah pelaksanaan harus konsisten jelas. Apabila terjadi pertentangan antara petunjuk pelaksana kebijakan dengan perintah-perintah pelaksanaan, maka akan menyulitkan para pelaksana kebijakan dalam menjalankan tugasnya dengan baik. Untuk mengetahui tanggapan responden terhadap item diatas, maka dapat dilihat pada tabel berikut ini :

\section{Tabel 5}

Tanggapan Responden Tentang Implementasi Kebijakan Dan Konsisten

\begin{tabular}{|c|l|c|c|}
\hline No. & $\begin{array}{c}\text { Klasifikasi } \\
\text { Jawaban }\end{array}$ & Frekuensi & $\begin{array}{c}\text { Persentase } \\
(\mathbf{\%})\end{array}$ \\
\hline 1 & Sangat Setuju & 24 & 64,9 \\
\hline 2 & Setuju & 12 & 32,4 \\
\hline 3 & $\begin{array}{l}\text { Kurang } \\
\text { Setuju }\end{array}$ & 1 & 2,7 \\
\hline 4 & Tidak Setuju & 0 & 0 \\
\hline 5 & $\begin{array}{l}\text { Sangat Tidak } \\
\text { Setuju }\end{array}$ & 0 & 0 \\
\hline & Total & $\mathbf{3 7}$ & $\mathbf{1 0 0}$ \\
\hline
\end{tabular}

Sumber : Hasil Olahan Data Primer, 2015

Hasil olahan data responden tentang implementasi kebijakan dan konsisten dapatlah di jabarkan bahwa 24 orang responden atau sekitar $64,9 \%$ memberikan tanggapan sangat setuju. Sementara itu 12 orang responden atau sebesar $32,4 \%$ memberikan tanggapan setuju implementasi kebijakan Dinas Pendapatan, Pengelola Keuangan dan Aset Kabupaten Donggala . Selanjutnya hanya 1 orang responden atau sebesar 2,7 yang memberikan pernyataan kurang setuju. Mengacu pada hasil pengolahan data pada tabel di atas, dapatlah disimpulkan bahwa responden memberikan tanggapan setuju tentang implementasi kebijakan yang ingin berlangsung efektif, maka perintah-perintah pelaksanaan harus konsisten jelas. Apabila terjadi pertentangan antara petunjuk pelaksana kebijakan dengan perintah-perintah pelaksanaan, maka akan 
menyulitkan para pelaksana kebijakan dalam menjalankan tugasnya.

Menyimak dari pernyataan responden di atas, maka hal senada juga dikemukakan oleh Ibu Hadjar Modjo Kepala Bidang Anggaran Daerah Dinas Pendapatan, Pengelola Keuangan dan Aset Kabupaten Donggala

Seperti yang telah dikemukakan bahwa kebijakan tersebut merupakan acuan dalam melaksanakan tugas, jadi kita harus konsisten dengan apa yang menjadi perintah dari kebijakan tersebut. Apabila terjadi pertentangan antara petunjuk pelaksana kebijakan dengan perintahperintah pelaksanaan, maka akan menyulitkan kita dalam menjalankan tugas. (Hasil wawancara, 7 Januari 2015)

\section{b. Sumber Daya}

Dinas Pendapatan, Pengelola Keuangan dan Aset Kabupaten Donggala sebagai lembaga teknis yang mempunyai tugas pokok membantu Bupati dalam meningkatkan pembangunan di bidang keuangan, telah berupaya semaksimal mungkin untuk melaksanakan tugas pokok dan fungsinya dengan menentukan kebijakan dan kebijaksanaan dalam rangka meningkatkan pelayanan kepada masyarakat atau pengguna jasa.

Sebuah kebijakan yang ditetapkan oleh Dinas Pendapatan, Pengelola Keuangan dan Aset Kabupaten Donggala bukan terlahir dari kepala atau seorang pimpinan saja. Sebuah kebijakan dapat dikatakan efektif dan efsien apabila dalam penyusunan kebijakan tersebut melibatkan publik, khususnya pegawai Dinas Pendapatan, Pengelola Keuangan dan Aset Kabupaten Donggala sendiri. Adanya saran dan masukan yang bersifat positif dari pegawai merupakan nilai tambah dalam penyusunan kebijakan, karena pegawai lebih mengetahui kebutuhan masyarakat sebagai pengguna jasa. Oleh karena itu jumlah pegawai dan professional pegawai, sarana dan prasaran sangat membantu sekali dalam penyusunan sebuah kebijakan.

Untuk mengetahui jumlah pegawai dalam menunjang penyusunan kebijakan Dinas Pendapatan, Pengelola Keuangan dan Aset Kabupaten Donggala , maka dapat dilihat pada tabel berikut ini:
Tabel 6

Tanggapan Responden Tentang Jumlah

Pegawai Dinas Pendapatan, Pengelola

Keuangan Dan Aset Kabupaten

Donggala

\begin{tabular}{|c|l|c|c|}
\hline No. & $\begin{array}{l}\text { Klasifikasi } \\
\text { Jawaban }\end{array}$ & Frekuensi & $\begin{array}{c}\text { Persentase } \\
(\boldsymbol{\%})\end{array}$ \\
\hline 1 & $\begin{array}{l}\text { Sangat } \\
\text { Setuju }\end{array}$ & 20 & 54,1 \\
\hline 2 & Setuju & 17 & 45,9 \\
\hline 3 & $\begin{array}{l}\text { Kurang } \\
\text { Setuju }\end{array}$ & 0 & 0 \\
\hline 4 & Tidak Setuju & 0 & 0 \\
\hline 5 & $\begin{array}{l}\text { Sangat Tidak } \\
\text { Setuju }\end{array}$ & 0 & 0 \\
\hline \multicolumn{2}{|l|}{ Total } & $\mathbf{3 7}$ & $\mathbf{1 0 0}$ \\
\hline
\end{tabular}

Sumber : Hasil Olahan Data Primer, 2015

Memperhatikan perolehan data hasil dari tanggapan responden pada tabel $4.8 \mathrm{di}$ atas dapatlah dijabarkan bahwa dari 37 orang responden, 20 orang responden menjawab sangat setuju atau sekitar $54,1 \%$ atau dengan kata lain bahwa sumber daya sudah sangat memadai, 17 orang responden mengatakan setuju atau sebesar 45,9\% sudah memenuhi standar bahwa jumlah pegawai dalam menunjang penyusunan kebijakan Dinas Pendapatan, Pengelola Keuangan dan Aset Kabupaten Donggala memadai.

Mengacu pada hasil data di atas Dengan demikian dapat pula dinyatakan bahwa responden meyatakan bahwa pegawai pada Dinas Pendapatan, Pengelola Keuangan dan Aset Kabupaten Donggala telah memadai dalam menunjang penyusunan kebijakan. Sumber daya manusia (SDM) merupakan elemen utama organisasi dibandingkan dengan elemen lain seperti modal, teknologi, dan uang, sebab manusia itu sendiri yang mengendalikan yang lain. Manusia memilih telnologi, manusia yang mencari modal, manusia yang menggunakan dan memelihara, disamping manusia dapat menjadi salah satu sumber keunggulan bersaing dan sumber keunggulan bersaing yang langgeng. 
Berbicara masalah sumber daya manusia, sebenarnya dapat kita lihat dari dua aspek, yakni kuantitas dan kualitas. Kuantitas menyangkut jumlah sumber daya manusia yang kurang penting kontribusinya dalam pembangunan, dibandingkan dengan aspek kualitas. Bahkan kuantitas sumber daya manusia tanpa disertai dengan kualitas yang baik akan menjadi beban pembangunan suatu bangsa. Sedangkan kualitas menyangkut mutu sumber daya manusia tersebut, yang menyangkut kemampuan, baik kemampuan fisik maupun kemampuan non fisik (kecerdasan dan mental).

Bila dilihat secara mikro, dalam arti di lingkungan suatu jenis kerja, maka sumber daya manusia yang dimaksud adalah pegawai atau karyawan. Sumber daya atau karyawan disuatu lembaga sangat penting perannya dalam mencapai keberhasilan lembaga atau departemen.

Sumber daya manusia merupakan modal dasar dari kebudayaan suatu bangsa. Modal fisik dan sumber daya alam hanyalah faktor produksi yang bersifat pasif. Manusia adalah agen-agen aktif yang mengumpulkan modal, mengeksploitasi sumber-sumber alam, membangun organisasiorganisasi sosial, ekonomi, dan politik, dan melaksanakan pembangunan nasional.

Selain jumlah pegawai, maka profesionalisme pegawai atau sumber daya manusia juga sangat mendukung dalam penyusunan kebijakan. Hasil penelitian terhadap data sekunder bahwa hampir sebagian sarjana yang bertugas di Dinas Pendapatan, Pengelola Keuangan dan Aset Kabupaten Donggala berlatarbelakang pendidikan S1 dan pernah mengikuti pendidikan dan pelatihan masalah keuangan.

Lebih jelasnya tentang tanggapan responden terhadap hal tersebut, dapat disimak dalam tabel berikut ini.

\section{Tabel 7}

Tanggapan Responden Tentang Profesionalisme Staf Atau Pegawai Pada Dinas Pendapatan, Pengelola Keuangan Dan Aset Kabupaten Donggala

\begin{tabular}{|c|l|c|c|}
\hline No. & $\begin{array}{l}\text { Klasifikasi } \\
\text { Jawaban }\end{array}$ & Frekuensi & $\begin{array}{c}\text { Persentase } \\
(\%)\end{array}$ \\
\hline 1 & $\begin{array}{l}\text { Sangat } \\
\text { Setuju }\end{array}$ & 24 & 64,9 \\
\hline 2 & Setuju & 13 & 35,1 \\
\hline 3 & $\begin{array}{l}\text { Kurang } \\
\text { Setuju }\end{array}$ & 0 & 0 \\
\hline
\end{tabular}

\begin{tabular}{|c|l|c|c|}
4 & Tidak Setuju & 0 & 0 \\
\hline 5 & $\begin{array}{l}\text { Sangat Tidak } \\
\text { Setuju }\end{array}$ & 0 & 0 \\
\hline \multicolumn{2}{|c|}{ Total } & $\mathbf{3 7}$ & $\mathbf{1 0 0}$ \\
\hline
\end{tabular}

Sumber : Hasil Olahan Data Primer, 2015

Tabel di atas dapat di lihat bahwa sebanyak 24 orang responden yang menjawab setuju atau sebesar $64,9 \%$ memberikan tanggapan bahwa profesionalisme staf atau pegawai pada Dinas Pendapatan, Pengelola Keuangan dan Aset Kabupaten Donggala sangat memadai dalam menunjang penyusunan kebijakan. Sedangkan sebanyak 13 orang responden menjawab setuju atau sebesar $35,1 \%$ mengatakan memadai. Mengacu pada konfigurasi jawaban responden maka dapatlah disimpulkan bahwa walaupun masih terdapat beberapa orang rersponden yang memberikan jawaban kurang dan tidak profesional terhadap pernyataan di atas, namun secara akumulatif dapatlah dikatakan bahwa responden menyatakan bahwa staf atau pegawai pada Dinas Pendapatan, Pengelola Keuangan dan Aset Kabupaten Donggala professional dalam menunjang penyusunan kebijakan.

Dinas Pendapatan, Pengelola Keuangan dan Aset Kabupaten Donggala sebagai lembaga teknis dengan tugas pokok dan fungsi membentu Bupati dalam penyelenggaraan pembangunan di bidang keuangan pada dasarnya telah didukung oleh 100 orang pegawai. Dari jumlah pegawai tersebut sebagian besar berlatarbelakang pendidikan S1, sehingga mendukung sekali dalam menyusun dan melaksanakan kebijakan. Seperti yang dikemukakan Ajis, Sekretaris Dinas Pendapatan, Pengelola Keuangan dan Aset Kabupaten Donggala .

Sumber daya manusia merupakan salah satu faktor penentu dalam penyusunan dan melaksanakan kebijakan. Seperti yang kita ketahui bahwa Dinas Pendapatan, Pengelola Keuangan dan Aset Kabupaten Donggala sebagai lembaga teknis ditunjang dengan 52 orang pegawai yang sebagian besar berijasah $\mathrm{S} 1$ dan pernah mengikuti berbagai pendidikan dan pelatihan masalah keuangan. Jadi dengan keberadaan jumlah pegawai tersebut, maka setiap kebijakan yang tetapkan tentunya efektif dan efisien. (Hasil wawancara, 6 Januari 2015)

Sub indikator selanjutnya yaitu sarana dan prasarana dalam mununjang kebijakan Dinas Pendapatan, Pengelola Keuangan dan Aset Kabupaten Donggala dalam meningkatkan 
efektifitas pelayanan. sarana prasarana Dinas Pendapatan, Pengelola Keuangan dan Aset Kabupaten Donggala dalam mendukung kebijakan memiliki peran yang sangat penting. Fungsi sarana prasarana ini adalah dalam kerangka mendukung mobilitas, pengiriman informasi penting serta menegakkan kebijakan.

Tanggapan responden terhadap sarana dan prasarana pada Dinas Pendapatan, Pengelola Keuangan dan Aset Kabupaten Donggala dalam rangka menunjang dan kebijakan dalam upaya meningkatkan efektifitas pelayanan, maka dapat disimak pada tabel berikut ini:

Tabel 8

Tanggapan Responden Sarana Dan

Prasarana Pada Dinas Pendapatan,

Pengelola Keuangan Dan Aset Kabupaten Donggala

\begin{tabular}{|c|l|c|c|}
\hline No. & $\begin{array}{l}\text { Klasifikasi } \\
\text { Jawaban }\end{array}$ & Frekuensi & $\begin{array}{c}\text { Persentase } \\
(\boldsymbol{\%})\end{array}$ \\
\hline 1 & Sangat Setuju & 23 & 62,2 \\
\hline 2 & Setuju & 6 & 16,2 \\
\hline 3 & $\begin{array}{l}\text { Kurang } \\
\text { Setuju }\end{array}$ & 6 & 16,2 \\
\hline 4 & Tidak Setuju & 2 & 5,4 \\
\hline 5 & $\begin{array}{l}\text { Sangat Tidak } \\
\text { Setuju }\end{array}$ & 0 & 0 \\
\hline \multicolumn{2}{|c|}{ Total } & $\mathbf{3 7}$ & $\mathbf{1 0 0}$ \\
\hline
\end{tabular}

Sumber : Hasil Olahan Data Primer, 2015

Hasil tanggapan responden terhadap sarana dan prasarana dalam menunjang kebijakan terhadap efektifitas pelayanan pada Dinas Pendapatan, Pengelola Keuangan dan Aset Kabupaten Donggala , menunjukkan bahwa dari 37 responden yang telah ditetapkan, sebanyak 23 orang yang mengatakan setuju atau sebesar $62,2 \%$ atau dengan kata lain memberikan tanggapan sangat memadai efektifitas pemberian pelayanannya, sementara itu 6 orang responden yang menjawab setuju atau sekitar 16,2\% memberikan tanggapan bahwa sarana dan prasarana pada Dinas Pendapatan, Pengelola Keuangan dan Aset Kabupaten Donggala memadai dalam menunjang kebijakan, dan 6 orang responden yang mengatakan kurang setuju atau sebesar 16,2\% memberikan tanggapan kurang memadai. Namun dari 37 responden, 2 orang yang menjawab tidak setuju atau sebesar $5,4 \%$ yang memberikan tanggapan tidak memadai.

Mengacu pada hasil pengolahan data di atas, maka secara umum dapat dikategorikan bahwa responden memberikan tanggapan bahwa sarana dan prasarana dalam menunjang kebijakan terhadap efektifitas pelayanan pada Dinas Pendapatan, Pengelola Keuangan dan Aset Kabupaten Donggala memadai namun perlu ditingatkan. Hal tersebut dapat dilihat pada sarana penunjang yang terdapat di Dinas Pendapatan, Pengelola Keuangan dan Aset Kabupaten Donggala. Sebagai pembantu bupati dalam bidang pengelolaan keuangan yang juga merupakan lembaga teknis, sarana dan prasarana masih perlu adanya pengembangan, misalnya sarana informasi teknologi yang hingga saat ini belum on line. Selain itu UPTD sebagai pembantu Kepala Dinas di tiap kecamatan juga belum terbentuk.

Pernyataan yang sama juga dikemukakan oleh Richard D. Machmud, Kepala Sub Bidang Pajak dan Retribusi Dinas Pendapatan, Pengelola Keuangan dan Aset Kabupaten Donggala

Kita akui bahwa sarana dan prasarana khususnya masalah IT masih perlu dilakukan pengembangan. Karena sarana tersebut untuk masa sekarang memang sangat menentukan untuk kemajuan lembaga. Dengan adanya IT maka akan dengan mudah mengakses berbagai informasi dari luar yang ada kaitannya dengan masalah keuangan. (Hasil wawancara, 10 januari 2015).

Hal senada juga dikemukakan oleh Ummi Asnita, Kepala Bidang Investasi dan Pinjaman Daerah : Seharusnya Dinas Pendapatan, Pengelola Keuangan dan Aset Kabupaten Donggala memprioritaskan pengadaan sarana informasi yang dilengkapi dengan internet. Sebagai Kepala Seksi kami sangat mengharapkan hal itu, karena kabupaten Donggala terdiri dari beebrapa kecamatan, sehingga untuk menunjang hal tersebut sangat dibutuhkan sarana informasi yang cepat, tepat, dan akurat, sementara di Dinas Pendapatan, Pengelola Keuangan dan Aset Kabupaten Donggala sendiri belum dilengkapi dengan sarana informasi yang memadai dan internet untuk mengakses informasi. (Hasil wawancara, 10 Januari 2015)

Menyimak hasil tanggapan responden di atas, dapatlah dikemukakan bahwa sarana informasi dalam bidang keuangan masih perlu peningkatan. Karena dapat membantu dalam pelaksanaan pembangunan di Kabupaten Donggala khususnya.

\section{c. Dampak (dispositions)}

Keberhasilan kebijakan yang telah ditetapkan oleh Dinas Pendapatan, Pengelola 
Keuangan dan Aset Kabupaten Donggala dapat diukur dan dilihat dari partisipasi atau kecenderungan masyarakat sebagai pengguna jasa dalam memberikan sikap atau memberi dukungan terhadap pelaksanaan kebijakan tersebut. Seperti yang dinyatakan responden dalam tabel berikut ini:

Tabel 9

Tanggapan Responden Terhadap Sikap Pelaksana Kebijakan

\begin{tabular}{|c|l|c|c|}
\hline No. & $\begin{array}{l}\text { Klasifikasi } \\
\text { Jawaban }\end{array}$ & Frekuensi & $\begin{array}{c}\text { Persentase } \\
(\boldsymbol{\%})\end{array}$ \\
\hline 1 & Sangat Setuju & 27 & 73,0 \\
\hline 2 & Setuju & 9 & 24,3 \\
\hline 3 & $\begin{array}{l}\text { Kurang } \\
\text { Setuju }\end{array}$ & 1 & 2,7 \\
\hline 4 & Tidak Setuju & 0 & 0 \\
\hline 5 & $\begin{array}{l}\text { Sangat Tidak } \\
\text { Setuju }\end{array}$ & 0 & 0 \\
\hline \multicolumn{2}{|l|}{ Total } & $\mathbf{3 7}$ & $\mathbf{1 0 0}$ \\
\hline
\end{tabular}

Sumber : Hasil Olahan Data Primer, 2015

Hasil tanggapan responden tentang sikap pelaksana kebijakan dalam memberi dukungan terhadap pelaksanaan kebijakan, maka dari 37 responden, 27 orang responden yang menjawab sangat setuju atau sekitar $73,0 \%$ memberikan jawaban selalu, dan 9 orang responden yang menjawab setuju atau sebanyak 24,3\% memberikan tanggapan sering. Sementara 1 responden lainnya menjawab kurang setuju atau sebanyak 2,7\% menjawab kadang-kadang. memberi dukungan terhadap pelaksanaan kebijakan. Menyimak tanggapan responden diatas dapatlah disimpulkan bahwa responden menyatakan sikap pelaksana kebijakan tidak pernah memberi dukungan terhadap pelaksanaan kebijakan.

Sikap kurang baik pelaksana kebijakan dalam memberi dukungan terhadap pelaksanaan kebijakan tersebut, dari hasil penelitian menunjukkan bahwa hanya dilakukan oleh individual atau oknum tertentu dengan alasan bahwa oknum tersebut kurang memahami apa isi dari kebijakan tersebut. Olehnya itu untuk mengefektifkan kebijakan tersebut, maka Pihak Dinas Pendapatan, Pengelola Keuangan dan Aset Kabupaten Donggala secara kontinyu melakukan penyuluhan dan sosialisasi terhadap kebijakan tersebut. Seperti yang dikemukakan oleh Hj. Fajra Kepala Sub Bagian Kegawaian dan Umum.
Memang masih ada beberapa masyarakat yang belum mengetahui adanya kebijakan dan bahkan ada juga pegawai pada Dinas Peternakan yang belum memahami kebijakan tersebut. Olehnya itu pihak Dinas Pendapatan, Pengelola Keuangan dan Aset Kabupaten Donggala secara kontinyu dan rutin melakukan sosialisasi dan penyuluhan kepada masyarakat tentang kebijakan tersebut, dengan harapan mampu memberikan kontribusi positif terhadap kebijakan tersebut. (Hasil wawancara, 8 Januari 2015)

Apabila diperhatikan bahwa keberhasilan sebuah kebijakan bukan hanya terletak pada sikap pelaksana saja, tetapi keberhasil kebijakan juga tergantung yang membuat kebijakan. Apabila perilaku-perilaku pembuat kebijakan berbeda dengan pelaksana kebijakan, maka dapat dipastikan bahwa implementasi kebijakan menjadi sulit. Untuk menyikapi pernyataan di atas, maka dapat dilihat dari tanggapan responden berikut ini:

Tabel 10

Tanggapan Responden Tentang PerilakuPerilaku Pembuat Kebijakan

\begin{tabular}{|c|l|c|c|}
\hline No. & $\begin{array}{l}\text { Klasifikasi } \\
\text { Jawaban }\end{array}$ & Frekuensi & $\begin{array}{c}\text { Persentase } \\
(\mathbf{\%})\end{array}$ \\
\hline 1 & $\begin{array}{l}\text { Sangat } \\
\text { Setuju }\end{array}$ & 33 & 89,2 \\
\hline 2 & Setuju & 4 & 10,8 \\
\hline 3 & $\begin{array}{l}\text { Kurang } \\
\text { Setuju }\end{array}$ & 0 & 0 \\
\hline 4 & Tidak Setuju & 0 & 0 \\
\hline 5 & $\begin{array}{l}\text { Sangat Tidak } \\
\text { Setuju }\end{array}$ & 0 & 0 \\
\hline \multicolumn{2}{|}{ Total } & $\mathbf{3 7}$ & $\mathbf{1 0 0}$ \\
\hline
\end{tabular}

Sumber : Hasil Olahan Data Primer, 2015

Hasil penelitian terhadap item ini menunjukkan bahwa 33 orang responden yang menyatakan setuju atau sebanyak $89,2 \%$ dan 4 orang yang menyatakan setuju atau sebesar $10,8 \%$ sedangkan tidak setuju bahkan sangat tidak setuju tidak ada, hal ini menunjukkan apabila perilakuperilaku pembuat kebijakan berbeda dengan pelaksana kebijakan, maka dapat dipastikan bahwa implementasi kebijakan menjadi sulit, sehingga secara tidak langsung mengatakan 
bahwa pelaksanaan kebijakan dapat terlaksana dengan baik apabila sikap pelaksana yang baik ditambah dengan yang membuat kebijakan betulbetul melaksanakan tugas. Mengacu pada hasil perhitungan di atas, maka dapatlah dikemukakan bahwa responden tidak setuju apabila perilakuperilaku pembuat kebijakan sesuai dengan pelaksana kebijakan, karena pimpinan sebagai pembuat kebijakan tentunya tidak hanya berdasarkan kepentingan pribadi, tetapi tetap mengacu pada kepentingan publik. Dalam menentukan sebuah kebijakan seorang pimpinan tetetap menerima saran dan masukan dari pihak yang terkait yang mengetahui persis kondisi di lapangan. Sehingga wajar apabila responden menyatakan kurang setuju apabila perilakuperilaku pembuat kebijakan berbeda dengan pelaksana kebijakan.

\section{d. Birokrasi}

Birokrasi pada prinsipnya merupakan suatu gambaran akan tugas pokok dan fungsi setiap organisasi, di mana dengan adanya birokrasi yang baik akan memberikan kejelasan mengenai batasan kewenangan dan tanggung jawab setiap pengurus atau anggota yang terlibat.

Melalui birokrasi dapat dijadikan sebagai alat untuk membantu mengatasi berbagai permasalahan dan keterbatasan manusia dengan jalan mendistribusikan tugas-tugas secara merata, sehingga tujuan organisasi dapat berhasilguna dan berdayaguna. Dari susunan organisasi Dinas Pendapatan, Pengelola Keuangan dan Aset Kabupaten Donggala, maka dapat diketahui mengenai birokarasi, wewenang dan tanggung jawab dari sekelompok orang-orang yang terlibat dalam hubungan kerja sama yang ada pada kantor tersebut. Selain itu birokrasi juga akan memberikan gambaran mengenai sistem kerja dalam menunjang pelaksanaan kebijakan.

Keberhasilan Dinas Pendapatan, Pengelola Keuangan dan Aset Kabupaten Donggala dalam melaksanakan kebijakan juga dipengaruhi birokrasi yang telah ditetapkan. Sistem atau pola yang digunakan dalam berbagai urusan Dinas, misalnya dalam hal pelayanan kepada masyarakat merupakan salah satu wujud dari pelaksanaan kebijakan yang telah ditetapkan. Oleh karena itu untuk mengetahui tanggapan responden terhadap kemampuan Dinas Pendapatan, Pengelola Keuangan dan Aset Kabupaten Donggala melaksanakan kebijakan, maka dapat disimak dalam tabel berikut ini:
Tabel 11

Tanggapan Responden Tentang Kemampuan Dinas Pendapatan, Pengelola Keuangan Dan Aset Kabupaten Donggala Melaksanakan Kebijakan

\begin{tabular}{|c|l|c|c|}
\hline No. & $\begin{array}{c}\text { Klasifikasi } \\
\text { Jawaban }\end{array}$ & Frekuensi & $\begin{array}{c}\text { Persentase } \\
(\mathbf{\%})\end{array}$ \\
\hline 1 & Sangat Setuju & 24 & 64,9 \\
\hline 2 & Setuju & 12 & 32,4 \\
\hline 3 & Kurang Setuju & 1 & 2,7 \\
\hline 4 & Tidak Setuju & 0 & 0 \\
\hline 5 & $\begin{array}{l}\text { Sangat Tidak } \\
\text { Setuju }\end{array}$ & 0 & 0 \\
\hline & Total & $\mathbf{3 7}$ & $\mathbf{1 0 0}$ \\
\hline
\end{tabular}

Sumber : Hasil Olahan Data Primer, 2015

Tanggapan responden terhadap kemampuan Dinas Pendapatan, Pengelola Keuangan dan Aset Kabupaten Donggala melaksanakan kebijakan sebagai implementasi (penjabaran) kebijakan publik yang terdapat pada tabel di atas, dapatlah dikemukakan bahwa dari 37 orang responden, 24 orang yang menjawab setuju atau sebanyak 64,9\% yang mengatakan sangat mampu melaksanakan implementasi kebijakan publik, responden yang menjawab setuju sebanyak 12 orang atau sebesar $32,4 \%$ atau menjawab mampu mengimplementasikan kebijakan dinas dan yang menjawab kurang setuju sebanyak 1 orang memberikan tanggapan tidak mampu tentang pernyataan item di atas. Walaupun masih terdapat beberapa responden yang memberikan tanggapan kurang mampu terhadap item diatas, tetapi secara umum dapat dikategorikan bahwa responden memberikan tanggapan bahwa Dinas Pendapatan, Pengelola Keuangan dan Aset Kabupaten Donggala mampu melaksanakan kebijakan, karena Dinas Pendapatan, Pengelola Keuangan dan Aset Kabupaten Donggala telah ditunjang dengan sumber daya manusia yang berlatar belakang pendidikan sarjana dan berpengalaman dalam pengelolaan keuangan.

Pembahasan dalam sub variabel berikutnya yaitu masalah struktur organisasi. Organisasi dapat dikatakan merupakan suatu yang 
sangat dibutuhkan dan urgen dalam satu organisasi untuk mewujudkan pembagian kerja dengan memberikan wewenang dan tanggung jawab tertentu. Dengan kata lain bahwa birokrasi adalah pengorganisasian untuk menciptakan keteraturan dan ketertiban dalam mewujudkan kerja sama sejumlah orang yang bermaksud mencapai tujuannya.

Organisasi yang dimaksudkan dalam penelitian ini adalah struktur organisasi Dinas Pendapatan, Pengelola Keuangan dan Aset Kabupaten Donggala yang merupakan sekumpulan tugas dan jabatan yang terorganisasi secara formal, dimana sistem pelaksanaan kerjanya berpegang pada hirarki dan jabatan yang berisi wewenang dan tanggung jawab, serta setiap unit/satuan kerja saling berpengaruh dan menentukan dalam pelaksanaan pekerjaan untuk mencapai tujuan organisasi.

Struktur organisasi dalam setiap SKPD terbentuk berdasarkan Peraturan Pemerintah maupun Peraturan Daerah. struktur organisasi yang telah ditetapkan dalam Peraturan Daerah tersebut dibuat agar mampu melaksanakan kebijakan dan meningkatkan pelayanan kepada masyarakat sesuai dengan tugas pokok dan fungsi yang telah ditetapkan.

Untuk mengetahui bagaimana peningkatan pelayanan kepada masyarakat berkaitan dengan struktur organisasi pada Dinas Pendapatan, Pengelola Keuangan dan Aset Kabupaten Donggala, maka dapat disimak pada tabel berikut ini:

Tabel 12

Tanggapan Responden Tentang Struktur Organisasi

\begin{tabular}{|c|c|c|c|}
\hline No. & $\begin{array}{c}\text { Klasifikasi } \\
\text { Jawaban }\end{array}$ & Frekuensi & $\begin{array}{c}\text { Persentase } \\
(\%)\end{array}$ \\
\hline 1 & $\begin{array}{l}\text { Sangat } \\
\text { Setuju }\end{array}$ & 20 & 54,1 \\
\hline 2 & Setuju & 7 & 45,9 \\
\hline 3 & $\begin{array}{l}\text { Kurang } \\
\text { Setuju }\end{array}$ & 0 & 0 \\
\hline 4 & Tidak Setuju & 0 & 0 \\
\hline 5 & $\begin{array}{l}\text { Sangat Tidak } \\
\text { Setuju }\end{array}$ & 0 & 0 \\
\hline \multicolumn{2}{|r|}{ Total } & 37 & 100 \\
\hline
\end{tabular}

Sumber : Hasil Olahan Data Primer, 2015

Hasil penelitian terhadap item ini menunjukkan bahwa 20 responden yang menjawab setuju atau sebanyak $54,1 \%$ bahwa dengan adanya struktur organisasi yang telah ditetapkan dalam Peraturan Daerah tersebut pelayanan kepada masyarakat sangat meningkat sesuai dengan tugas pokok dan fungsi. Sebanyak 17 responden yang menjawab setuju atau sebanyak 45,9\% menjawab meningkat. Berdasarkan hasil pengolahan data, seperti yang tampak pada tabel di atas dapatlah dijabarkan bahwa hasil tanggapan responden tentang struktur organisasi yang telah ditetapkan dalam Peraturan Daerah dalam meningkatkan pelayanan kepada masyarakat meningkat sesuai dengan tugas pokok dan fungsi. Hal tersebut sangatlah wajar, karena struktur yang dibentuk telah memalui berbagai survey dan saran dari bidang akademik. Selain itu dalam setiap bidang dan seksi sudah jelas adanya tugas pokok dan fungsi yang harus dilaksanakan dalam mengimplementasikan kebijakan.

Seperti yang dikemukakan oleh Ajis Sekretaris Dinas Pendapatan, Pengelola Keuangan dan Aset Kabupaten Donggala

Dengan diberlakukannya PP No 41 Tahun 2007 tentang Kelembagaan serta Dinas Pendapatan, Pengelola Keuangan dan Aset Kabupaten Donggala ditunjang dengan jumlah pegawai yang memadai, maka dua hal tersebut menjadi acuan bahwa Dinas Pendapatan, Pengelola Keuangan dan Aset Kabupaten Donggala mampu melaksanakan kebijakan. Hal tersebut dapat dilihat bahwa dengan kemampuan yang dimiliki serta ditunjang dengan struktur organisasi, yang dikomadoi oleh sumber daya yang professional, maka pelayanan dapat ditingkatkan. (Hasil wawancara, 6 januari 2015)

Pungutan dalam bentuk pajak Iklan berdasarkan Undang Undang Nomor 18 Tahun 1997 tentang Pajak dan Retribusi Daerah, dan Peraturan Pemerintah Republik Indonesia Nomor 19 Tahun 1997 tentang pajak dan retribusi daerah, yang kemudian menjadi dasar Peraturan Daerah Kabupaten DonggalaNomor 11 Tahun 2010 tentang Pajak Reklame.

Pajak reklame yang selanjutnya disebut pajak adalah pembayaran atas pelayanan tempat kegiatan usaha, fasilitas lainnya dilingkungan umum yang dimiliki dan atau dikelola oleh Pemerintah Daerah. Pajak termasuk dalam pajak atau retribusi atas jasa yang disediakan oleh 
pemerintah daerah dengan penganut prinsip komersial karena pada dasarnya dapat pula disediakan oleh sektor swasta.

Dengan diterapkannya Undang Undang Nomor 32 Tahun 2004 tentang Pemerintah Daerah, yang bermakna Otonomi Daerah, maka pemerintah daerah dituntut untuk dapat memberikan pelayanan yang semaksimal mungkin terhadap masyarakat disamping tuntutan untuk menggali potensi sumber penerimaan khususnya bagi Pendapatan Asli Daerah (PAD). Sebab Pendapatan Asli Daerah merupakan salah satu sumber pembiayaan aktivitas pemerintah baik yang bersifat rutin maupun pembangunan, sehingga sumber penerimaan daerah ini memiliki peranan penting terhadap kelancaran roda pemerintahan, pembangunan dan kemasyarakatan. Sebagai salah satu sumber Pendapatan Asli Daerah (PAD), maka pemungutan retribusi ini dimaksudkan sebagai salah satu upaya peningkatan jasa pelayanan oleh Pemerintah Daerah untuk tujuan kepentingan dan pemanfaatan bagi masyarakat umum, serta menjadi sumber penerimaan pendapatan asli daerah, dengan demikian retribusi daerah dikenakan atas penyediaan jasa oleh Pemerintah Daerah.

Saat ini, upaya utuk memberikan layanan yang berkualitas kepada pelanggan menjadi perhatian utama dari berbagai organisasi di seluruh dunia, baik organisasi privat maupun publik. Keterbukaan informasi juga ikut mendorong masyarakat kian sadar tentang hak dan kewajibannya dikaitkan dengan aktifitas pelayanan. Oleh karea itu, harapan untuk bisa mendapatkan pelayanan yang terbaik tersebut kini juga mulai digantungkan kepada organisasi pemerintahan.

Pelayanan pajak Reklame merupakan salah satu unsur penting yang menentukan berhasilnya suatu organisasi dalam menjalankan fungsi dan tugasnya. Pelayanan yang baik adalah pelayanan yang tepat mengenai sasaran, dalam arti pelayanan yang diberikan dapat memenuhi harapan dan kebutuhan pemakainya, untuk memenuhi harapan dan kebutuhan pemakai. Ketepatan sasaran dalam pelayanan pajak Reklame yang dilaksanakan oleh Dinas Pendapatan Daerah Kabupaten Donggala merupakan tujuan yang telah direncanakan. Dinas Pendapatan Daerah Kabupaten Donggala dalam melakukan pelayanan perlu memperhatikan sasaran yang akan dilayani termasuk ketepatan sasaran yang akan dicapai. Berikut ini diberikan hasil tanggapan responden terhadap ketepatan sasaran dalam pelayanan pajak Reklame.

Tabel 13

Tanggapan Responden Terhadap Ketepatan Sasaran Dalam Pelayanan Pajak Reklame

\begin{tabular}{|c|c|c|c|}
\hline No. & $\begin{array}{l}\text { Klasifikasi } \\
\text { Jawaban }\end{array}$ & Frekuensi & $\begin{array}{c}\text { Persentase } \\
(\%)\end{array}$ \\
\hline 1 & $\begin{array}{l}\text { Sangat } \\
\text { Setuju }\end{array}$ & 24 & 64,9 \\
\hline 2 & Setuju & 13 & 35,1 \\
\hline 3 & $\begin{array}{l}\text { Kurang } \\
\text { Setuju }\end{array}$ & 0 & 0 \\
\hline 4 & Tidak Setuju & 0 & 0 \\
\hline 5 & $\begin{array}{l}\text { Sangat Tidak } \\
\text { Setuju }\end{array}$ & 0 & 0 \\
\hline \multicolumn{2}{|r|}{ Total } & 37 & 100 \\
\hline
\end{tabular}

Sumber : Hasil Olahan Data Primer, 2015

Tabel di atas menunjukkan bahwa responden hanya menjawab sangat setuju dan setuju. Banyaknya responden yang menjawab sangat setuju sebesar 24 orang atau sebanyak $64,9 \%$ yang memberikan pernyataan bahwa pelayanan pajak Reklame yan dilaksanakan Dinas Pendapatan Daerah Kabupaten Donggala sangat tepat sasaran, sementara itu 13 orang responden yang menyatakan setuju atau sebnayak 35,1\% memberikan pernyataan bahwa pelayanan pajak Reklame tersebut tepat sasaran. Dengan persentase perhitungan persentase di atas maka dapat diidentifikasi bahwa secara umum para responden memberikan tanggapan terhadap pelayanan pajak Reklame yang dilaksanakan oleh Dinas Pendapatan Daerah Kabupaten Donggala sudah cukup tepat pada sasaran yang telah ditetapkan.

Hal tersebut juga diungkapkan oleh Nuryadin (34 tahun) salah satu staf Bagian Pajak Dinas Pendapatan Daerah Kabupaten Donggala .

Untuk memberikan kepuasan kepada para pelanggan yang berkaitan dengan pajak Reklame, maka sesuai dengan moto Dinas Pendapatan Daerah Kabupaten Donggala ini kami selalu memberikan pelayanan sebaik mungkin, apa yang kita janjikan selalu kami laksanakan dan kami penuhi tepat pada waktunya. Dengan adanya ketepatan dalam pelayanan, maka sasaran yang 
telah ditetapkan dapat tercapai. Kecuali ada halhal yang sifatnya sangat teknis yang memerlukan konsultasi dengan pimpinan dan adanya hambatan yang tak terduga, misalnya masalah listrik dan sebagainya, (Hasil wawancara, 10 Januari 2015).

Pajak terhadap Reklame dipungut sebagai pembayaran atas pemakaian listrik yang digunakan oleh seseorang atau badan dalam melaksanakan suatu pekerjaan yang dikelola oleh Pemerintah Daerah, dan pembayaran pajak Reklame tersebut dilaksanakan oleh Dinas Pendapatan Daerah.

Dengan diterapkannya Undang Undang Nomor 32 Tahun 2004 tentang Pemerintah Daerah, yang bermakna Otonomi Daerah, maka pemerintah daerah dituntut untuk dapat memberikan pelayanan yang semaksimal mungkin terhadap masyarakat atau pengguna jasa pada Dinas Pendapatan Daerah Kabupaten Donggala dalam pemakaian kekayaan daerah yaitu listrik, disamping tuntutan untuk menggali potensi sumber penerimaan khususnya bagi Pendapatan Asli Daerah (PAD). Sebab Pendapatan Asli Daerah merupakan salah satu sumber pembiayaan aktivitas pemerintah baik yang bersifat rutin maupun pembangunan, sehingga sumber penerimaan daerah ini memiliki peranan penting terhadap kelancaran roda pemerintahan, pembangunan dan kemasyarakatan.

\subsubsection{Kontribusi Pajak Reklame Terhadap Pendapatan Asli Daerah Kabupaten Donggala}

\section{a. Realisasi Pajak Reklame}

Sebagai salah satu sumber dari Pendapatan Asli Daerah (PAD), maka pemungutan pajak Reklame ini dimaksudkan sebagai salah satu upaya peningkatan jasa pelayanan oleh Pemerintah Daerah untuk tujuan kepentingan dan kemanfaatan umum serta sumber penerimaan pendapatan asli daerah, dengan demikian retribusi daerah dikenakan atas penyediaan jasa Pemerintah Daerah.

Kekayaan Daerah khususnya alat berat merupakan sarana dan prasarana dalam menunjang aktifitas seseorang maupun kelompok atau organisasi baik swasta maupun pemerintah dalam menyelesaikan pekerjaan, misalnya bangunan, perbaikan jalan serta hal-hal lain yang sifatnya memerlukan faktor pendukung yaitu masalah listrik, maka pengelolaan pajak Reklame sangat penting sebab pelayanan yang baik akan berdampak peningkatan pelayanan dan berpengaruh secara langsung terhadap peningkatan penerimaan, sedang pengelolaan yang buruk akan berpengaruh terhadap keengganan para pengguna jasa atau wajib pajak untuk membayarkan pajaknya.

Untuk mengetahui realisasi dari target yang telah ditetapkan oleh Dinas Pendapatan Daerah Kabupaten Donggala terhadap pajak Reklame , maka dapat dilihat pada tabel berikut ini :

\section{Tabel 14}

Target Dan Realisasi Pajak Reklame

\begin{tabular}{|c|l|r|r|c|}
\hline No. & \multicolumn{1}{|c|}{ Tahun } & $\begin{array}{c}\text { Target } \\
\text { (Rp) }\end{array}$ & Realisasi (Rp) & persentase \\
\hline 1. & 2011 & $60.000 .000,00$ & $59.926 .905,00$ & $99,9 \%$ \\
2. & 2012 & $62.000 .000,00$ & $78.555 .322,00$ & $126,7 \%$ \\
3. & 2013 & $98.040 .910,00$ & $101.953 .410,00$ & $104,0 \%$ \\
\hline
\end{tabular}

Sumber : Hasil Olahan Data Sekunder, 2015

Memperhatikan tabel 4.17 di atas dapatlah dijelaskan bahwa realisasi pada tahun 2011 tidak memenuhi target yang ditetapkan, dimana realisasi pajak reklame dibawah $100 \%$ yang hanya sebesar $99,9 \%$. Namun untuk target pada tahun 2012 telah menunjukkan peningkatan yang cukup optimal yaitu $126,7 \%$. Begitu pula pada tahun 2013 mengalami peningkatan sebesar 104\%, walaupun pada tahun 2013 target penerimaan pajak reklame terpenuhi namun persentase realisasi lebih rendah dari bandingkan dengan realisasi pada tahun 2012. Dengan melihat angkaangka yang tertera pada tabel 4.17 selanjutnya dapatlah diasumsikan bahwa pajak Reklame pada Dinas Pendapatan Daerah kabupaten Donggala secara umum meningkat, dan melampaui target yang telah ditetapkan, namun tingkat persentasi realisasinya menurun.

\section{b. Kontribusi Pajak Reklame Terhadap Pendapatan Asli Daerah \\ Pendapatan Asli Daerah merupakan salah} satu sumber dana yang digunakan pemerintah daerah dalam menjalankan roda pemerintah daerah, yang bersumber dari daerah itu sendiri dengan pajak dan retribusi daerah, yang dipungut Pemerintah Daerah.

Pajak Reklame yang merupakan salah satu Pajak Daerah yang menjadi sumber pendapatan pemerintah daerah. Yang memiliki kontribusi terhadap Pendapatan Asli Daerah. Dibawah ini dapat dilihat kontribusi Pajak Reklame terhadap PAD Kabupaten Donggala, yaitu:

Tabel 15

Kontribusi Pajak Reklame Terhadap PAD 


\begin{tabular}{|c|c|c|c|c|c|}
\hline \multirow[b]{2}{*}{ No. } & \multirow[b]{2}{*}{ Tahun } & Realisasi & Realisasi & \multirow[b]{2}{*}{$\%$} & \multirow[b]{2}{*}{ Klasifikasi } \\
\hline & & PAD (Rp) & $\begin{array}{c}\text { Pajak Reklame } \\
(\mathrm{Rp})\end{array}$ & & \\
\hline 1 & 2011 & Rp $18,884,567,534.00$ & Rp $59,926,905.00$ & $0.32 \%$ & Sangat Kurang \\
\hline 2 & 2012 & Rp $21,728,375,885.00$ & Rp $78,555,322.00$ & $0.36 \%$ & Sangat Kurang \\
\hline 3 & 2013 & Rp $32,926,073,886.00$ & Rp $101,953,410.00$ & $0.31 \%$ & Sangat Kurang \\
\hline
\end{tabular}

Berdasarkan tabel 4.18 kontribusi Pajak Reklame terhadap PAD pada tahun 2011 hanya $0.32 \%$ dari total realisasi PAD. Kemudian pada tahun 2012 kontribusi meningkat menjadi $0.36 \%$, namun pada tahu 2013 kontribusi turun bahkan lebih rendah dari kontribusi pada tahun 2011. Dari data terssebut menunjukkan kontribusi pajak reklame terhadap PAD mengalami tren penurunan dan juga klasifikasi kontribusinya terhadap PAD dari tahun 2011 sampai 2013 sangat kurang.

\subsubsection{Faktor Yang Mempengaruhi Realisasi Pajak Reklame Pendapatan Asli Daerah Kabupaten Donggala}

\section{a. Faktor penghambat dan pendukung realisasi tahun sebelumnya}

Dalam menetapkan target penerimaan pendapatan asli daerah DPPKAD harus memperhatikan faktor yang mendukung dan menghambat realisasi pajak reklame tahun sebelumnya, agar realisasi tahun berikutnya akan melampaui target bahkan kontribusinya terhadap PAD mengalami peningkatan. Dalam wawancara dengan Ibu Hadjar Modjo Kepala Bidang Anggaran Daerah Dinas Pendapatan, Pengelola Keuangan dan Aset Kabupaten Donggala, mengemukakan:

Dalam menetapkan target tahun berikutnya bagian anggaran di DPPKAD Kabupaten Donggala berpatokan dengan realisasi anggaran tahun sebelumnya. Sebagai acuan penyusunan anggaran tahun berikutnya. (Hasil wawancara, 7 Januari 2015).

Berikut akan dikemukakan pendapat responden tentang pengaruh faktor penghambat dan pendukung realisasi pajak reklame tahun sebelumnya dalam tabel 18 sebagai berikut
Tabel 16

Tanggapan Responden Terhadap Faktor Penghambat Dan Pendukung Realisasi Pajak Reklame Tahun Sebelumnya Berpengaruh Terhadap Realisasi Target Pajak Reklame Tahun Akan Datang

\begin{tabular}{|c|l|c|c|}
\hline No. & $\begin{array}{l}\text { Klasifikasi } \\
\text { Jawaban }\end{array}$ & Frekuensi & $\begin{array}{c}\text { Persentase } \\
(\mathbf{\%})\end{array}$ \\
\hline 1 & $\begin{array}{l}\text { Sangat } \\
\text { Setuju }\end{array}$ & 23 & 62,2 \\
\hline 2 & Setuju & 6 & 16,2 \\
\hline 3 & $\begin{array}{l}\text { Kurang } \\
\text { Setuju }\end{array}$ & 6 & 16,2 \\
\hline 4 & $\begin{array}{l}\text { Tidak } \\
\text { Setuju }\end{array}$ & 2 & 5,4 \\
\hline 5 & $\begin{array}{l}\text { Sangat } \\
\text { Tidak } \\
\text { Setuju }\end{array}$ & 0 & 0 \\
\hline \multicolumn{2}{|c|}{ Total } & $\mathbf{3 7}$ & $\mathbf{1 0 0}$ \\
\hline
\end{tabular}

Sumber : Hasil Olahan Data Primer, 2015

Dari tabel di atas menunjukkan bahwa responden yang menjawab sangat setuju sebanyak 23 orang atau sekitar $62,2 \%$ yang artinya bahwa terdapat faktor penghambat dan pendukung realisasi pajak reklame tahun sebelumnya sangat berpengaruh terhadap realisasi target pajak reklame tahun akan datang, 6 responden yang menyatakan setuju dan kurang setuju atau sebesar $16,2 \%$ yang artinya memberikan tanggapan kurang berpengaruh, sehingga disimpulkan bahwa faktor penghambat dan pendukung realisasi pajak reklame tahun sebelumnya berpengaruh terhadap realisasi target pajak reklame tahun akan datang pada Dinas Pendapatan Daerah kabupaten Donggala sudah baik. Indikasi yang dikemukakan oleh para responden ialah bahwa pengelolaan dari hari ke hari yang semakin baik dan mulai optimalnya pelaksanaan pemungutan yang terlihat dari semakin meningkatnya penerimaan

\section{b. Pencairan Tagihan Tahun Sebelumnya.}

Pencairan Tagihan pajak tahun sebelumnya di pengaruhi ketepatan waktu dalam penyelesaian iuran pajak, ketepatan waktu dalam penyelesaian iuran pajak merupakan salah satu wujud dalam memberikan kepuasan pelanggan atau para wajib pajak. Selain itu ketepatan waktu dalam 
penyelesaian iuran juga juga merupakan sikap yang sangat terpuji bagi para wajib pajak.

Ketepatan waktu dalam penyelesaian iuran pajak oleh pegawai dan para wajib pajak memberikan kontribusi kepada pemerintah daerah dalam upaya meningkatkan pendapatan asli daerah. Karena kewajiban para wajib pajak dan kewajiban pegawai pajak dalam menyelesaikan administrasi dapat terselesaikan tepat pada waktunya.

Berikut tanggapan responden tentang ketepatan waktu dalam penyelesaian iuran pajak Reklame pada Dinas Pendapatan Daerah Kabupaten Donggala , dapat disimak pada tabel di bawah ini :

Tabel 17

Tanggapan Responden Terhadap Ketepatan Waktu Dalam Penyelesaian Pajak

\begin{tabular}{|c|l|c|c|}
\hline No. & $\begin{array}{l}\text { Klasifikasi } \\
\text { Jawaban }\end{array}$ & Frekuensi & $\begin{array}{c}\text { Persentase } \\
(\mathbf{\%})\end{array}$ \\
\hline 1 & $\begin{array}{l}\text { Sangat } \\
\text { Setuju }\end{array}$ & 20 & 54,1 \\
\hline 2 & Setuju & 17 & 45,9 \\
\hline 3 & $\begin{array}{l}\text { Kurang } \\
\text { Setuju }\end{array}$ & 0 & 0 \\
\hline 4 & $\begin{array}{l}\text { Tidak } \\
\text { Setuju }\end{array}$ & 0 & 0 \\
\hline 5 & $\begin{array}{l}\text { Sangat } \\
\text { Tidak } \\
\text { Setuju }\end{array}$ & 0 & 0 \\
\hline \multicolumn{2}{|c|}{ Total } & $\mathbf{3 7}$ & $\mathbf{1 0 0}$ \\
\hline
\end{tabular}

Sumber : Hasil Olahan Data Primer, 2015

Tabel di atas menunjukkan bahwa 5 orang responden yang menjawab setuju atau sebesar $54,1 \%$ memberikan jawaban bahwa ketepatan waktu dalam penyelesaian iuran pajak Reklame sangat tepat waktu dengan waktu yang telah ditetapkan. Selanjutnya yang memberikan tanggapan tepat waktu atau setuju berjumlah 17 orang responden atau sebesar 45,9\%. Hasil dari tanggapan responden di atas menunjukkan bahwa ketepatan waktu dalam penyelesaian iuran pajak Reklame yang dilaksanakan oleh Dinas Pendapatan Daerah Kabupaten Donggala telah sesuai dengan waktu yang telah ditetapkan baik kepada para wajib pajak dalam menjalankan kewajibannya maupun para pegawai pelayanan pajak dalam menyelesaikan administrasi.

\section{c. Data Potensi dan Estimasi}

Potensi obyek pajak reklame yang dimiliki Kabupaten Donggala sebagai sumber Pendapatan Asli Daerah sangat potensial, ini bisa di lihat dari daftar perbandingan realisasi penerimaan Pendapatan Asli Daerah setiap tahun anggarannya, yang nantinya bisa diketahui seberapa besar kontribusi suatu pajak reklame terhadap Pendapatan Asli Daerah Donggala. Hal ini disebabkan karena wilayah Kabupaten Donggala yang strategis berada dijalan trans Sulawesi yang untuk dijadikan sebagai ajang promosi atau tempat pemasangan reklame, banyaknya industri atau perdagangan yang menjadikan banyaknya objek pajak reklame dan semakin banyaknya objek pajak reklame akan memperlancar pemasukan penerimaan dari pajak reklame.

Potensi Subyek Pajak Reklame Jumlah wajib pajak di Kabupaten Donggala setiap tahunnya mengalami kenaikan atau bertambah, hal ini disebabkan banyaknya perusahaan yang giat mempromosikan produk yang hasilkannya. Pemasukan pendapatan Pajak Reklame sudah bisa dibilang memenuhi target yang ditentukan..

Selanjutnya akan dikemukakan tanggapan responden tentang pengaruh potensi pajak reklame Kabupaten Donggala terhadap realisasi pajak reklame, dapat disimak pada tabel berikut ini :

Tabel 18

Pendapat Responden Tentang Pengaruh

Potensi Pajak Reklame Terhadap Realisasi Pajak Reklame

\begin{tabular}{|c|l|c|c|}
\hline No. & \multicolumn{1}{|c|}{$\begin{array}{c}\text { Klasifikasi } \\
\text { Jawaban }\end{array}$} & Frekuensi & $\begin{array}{c}\text { Persentase } \\
(\boldsymbol{\%})\end{array}$ \\
\hline 1 & Sangat Setuju & 24 & 64,9 \\
\hline 2 & Setuju & 13 & 35,1 \\
\hline 3 & Kurang Setuju & 0 & 0 \\
\hline 4 & Tidak Setuju & 0 & 0 \\
\hline 5 & $\begin{array}{l}\text { Sangat Tidak } \\
\text { Setuju }\end{array}$ & 0 & 0 \\
\hline & Total & $\mathbf{3 7}$ & $\mathbf{1 0 0}$ \\
\hline
\end{tabular}

Sumber : Hasil Olah Data Primer, 2015

Pengolahan data yang terdapat pada tabel di atas diketahui bahwa dari 37 responden, 24 orang yang menjawab sangat setuju atau sekitar $64,9 \%$ dan 13 orang yang menjawab setuju atau sebanyak $35,1 \%$ yang menyatakan bahwa potensi pajak reklame terhadap realisasi pajak reklame Kabupaten Donggala sangat berpengaruh, sehingga disimpulkan bahwa pengaruh potensi 
pajak reklame Kabupaten Donggala berpengaruh terhadap terhadap realisasi pajak reklame. Alasan yang dikemukakan responden untuk jawaban berpengaruh ialah bahwa dengan semakin tingginya potensi pajak di kabupaten donggala maka realisasi pajak reklame akan tercapai dan akan semakin meningkatkan kontribusi penerimaan pajak reklame terhadap Pendapatan Asli Daerah.

\section{d. Penyesuain Tarif Dan Penyempurnaan System Pungutan.}

Upaya yang dilakukan oleh suatu pemerintahan untuk meningkatan pendapatan daerah salah satunya adalah dari pajak. Dalam menentukan besarnya pajak dari beberapa obyek perlu diatur dalam suatu peraturan pemerintah. Dengan adanya peraturan daerah, maka hal tersebut merupakan acuan bagi para wajib pajak dalam memenuhi kewajibannya sebagai warga Negara. Pada dasarnya pajak yang dibebankan kepada masyarakat adalah untuk kelancaran dan peningkatan pembangunan.

Kesesuaian jumlah pembayaran pajak dari para wajib pajak sangat tergantung pada obyek pajak. Sehingga obyek pajak yang satu dengan yang lain ketetapan pajaknya tidak akan sama, misalnya pajak reklame dengan pajak perhotelan tentunya tidak sama besarnya dan semuanya telah diatur dalam peraturan daerah.

Oleh karena itu untuk mengetahui tanggapan responden terhadap kesesuaian jumlah pembayaran pajak reklame di Kabupaten Donggala , maka dapat dilihat pada hasil tanggapan responden di bawah ini :

\section{Tabel 19}

Tanggapan Responden Terhadap Kesesuaian Jumlah Pembayaran Pajak Reklame

\begin{tabular}{|c|l|c|c|}
\hline No. & $\begin{array}{l}\text { Klasifikasi } \\
\text { Jawaban }\end{array}$ & Frekuensi & $\begin{array}{c}\text { Persentase } \\
(\mathbf{\%})\end{array}$ \\
\hline 1 & $\begin{array}{l}\text { Sangat } \\
\text { Setuju }\end{array}$ & 23 & 62,2 \\
\hline 2 & Setuju & 6 & 16,2 \\
\hline 3 & $\begin{array}{l}\text { Kurang } \\
\text { Setuju }\end{array}$ & 6 & 16,2 \\
\hline 4 & $\begin{array}{l}\text { Tidak } \\
\text { Setuju }\end{array}$ & 2 & 5,4 \\
\hline 5 & $\begin{array}{l}\text { Sangat } \\
\text { Tidak } \\
\text { Setuju }\end{array}$ & 0 & 0 \\
\hline \multicolumn{2}{|c|}{ Total } & $\mathbf{3 7}$ & $\mathbf{1 0 0}$ \\
\hline
\end{tabular}

Sumber : Hasil Olahan Data Primer, 2015
Hasil pengolahan data pada tabel di atas dapatlah dijabarkan bahwa 23 orang responden yang menjawab setuju atau sebanyak $62,2 \%$ yang artinya memberikan tanggapan bahwa pembayaran pajak Reklame sangat sesuai. Sementara 6 orang responden yang mengatakan setuju dan kurang setuju atau sebanyak 16,2\% memberikan tanggapan bahwa pembayaran pajak reklame pada Dinas Pendapatan Daerah Kabupaten Donggala belum sesuai dengan peraturan yang telah ditetapkan oleh pemerintah daerah dan sesuai dengan peraturan daerah yang ada. Selanjutnya yang memberikan tanggapan tidak setuju sebanyak 2 orang responden atau sebanyak 5,4\%. Oleh karena itu sangat diperlukan pemasyarakatan peraturan daerah kepada masyarakat atau para wajib pajak sehingga jumlah pembayaran pajak yang disetor oleh para wajib pajak belum sesuai dengan target yang telah ditetapkan.

\section{e. Keadaan Sosial-ekonomi dan kesadaran wajib pajak}

Berkaitan dengan kondisi lingkungan ekonomi, sosial dan kesadaran wajib pajak berpengaruh besar kepada keberhasilan implementasi pajak reklame. Kebijakan yang diambil dapat dilaksanakan dengan baik apabila ditunjang oleh kondisi yang baik dari lingkungan luar. Berdasarkan hasil observasi pada Dinas Pendapatan Pengelolaan Keuangan dan Aset Kabupaten Donggala hal tersebut dirasakan kurang mendukung. Hal ini terlihat dari lingkungan ekonomi dan sector usaha kerakyat di wilayah kabupaten Donggala yang masih rendah.

Besar kecilnya penerimaan sektor pajak daerah terutama pajak reklame sangat dipengaruhi oleh kondisi sosial, ekonomi dan kesadaran wajib pajak. Maka jumlah penduduk berpengaruh terhadap jumlah penerimaan pajak reklame. Pertumbuhan penduduk dan angkatan kerja dianggap sebagai salah satu faktor yang positif dalam memacu pertumbuhan ekonomi. Penduduk dianggap sebagai pemacu pembangunan. Banyaknya jumlah penduduk akan memacu kegiatan produksi, konsumsi dari penduduk inilah yang akan menimbulkan peningkatan agregat. Pada saatnya peningkatan konsumsi agregat memungkinkan usaha- usaha produktif berkembang, begitu pula perekonomian secara keseluruhan.

Berikut akan dikemukakan pendapat responden tentang pengaruh kondisi sosial, 
ekonomi dan kesadaran wajib pajak terhadap realisasi pajak reklame dalam tabel 18 sebagai berikut:

Tabel 20

Tanggapan Responden Terhadap Pengaruh Kondisi Sosial, Ekonomi Dan Kesadaran Wajib Pajak Terhadap Realisasi Pajak Reklame

\begin{tabular}{|c|l|c|c|}
\hline No. & $\begin{array}{l}\text { Klasifikasi } \\
\text { Jawaban }\end{array}$ & Frekuensi & $\begin{array}{c}\text { Persentase } \\
(\mathbf{\%})\end{array}$ \\
\hline 1 & $\begin{array}{l}\text { Sangat } \\
\text { Setuju }\end{array}$ & 27 & 73,0 \\
\hline 2 & Setuju & 9 & 24,3 \\
\hline 3 & $\begin{array}{l}\text { Kurang } \\
\text { Setuju }\end{array}$ & 1 & 2,7 \\
\hline 4 & $\begin{array}{l}\text { Tidak } \\
\text { Setuju }\end{array}$ & 0 & 0 \\
\hline 5 & $\begin{array}{l}\text { Sangat } \\
\text { Tidak } \\
\text { Setuju }\end{array}$ & 0 & 0 \\
\hline \multicolumn{2}{|c|}{ Total } & $\mathbf{3 7}$ & $\mathbf{1 0 0}$ \\
\hline
\end{tabular}

Sumber : Hasil Olahan Data Primer, 2015

Dari tabel 18 di atas menunjukkan bahwa 27 responden menjawab sangat setuju atau sebanyak 73,0\% berpendapat bahwa kondisi sosial, ekonomi dan kesadaran wajib pajak terhadap realisasi pajak reklame Kabupaten Donggala telah menunjukkan berpengaruh, 9 responden yang menjawab setuju atau sebanyak $24,3 \%$ dan tidak setuju sebanyak 1 orang atau sekitar 2,7\%, sehingga disimpulkan bahwa pengaruh kondisi sosial, ekonomi dan kesadaran wajib pajak terhadap realisasi pajak reklame kabupaten Donggala kurang berpengaruh. Indikasi yang dikemukakan oleh para responden ialah bahwa rendahnya tingkat konsumsi masyarakat menyebabkan kegiatan promosi menjadi rendah dan sektor usaha produksi rakyat sangat rendah menyebabkan kegiatan promosi atas barang produksipun rendah. Kemudian tingkat kesadaran wajib pajak juga rendah.

\section{f. Kebijakan ekonomi dan moneter}

Besar kecilnya penerimaan pajak daerah sangat di tentukan oleh kebijakan pemerintah baik pusat maupun daerah, dimana kebijakan ekonomi dan moneter yang meningkatkan kegiatan produksi dan konsumsi masyarakat Kabupaten Donggala maka akan meningkatkan pajak daerah terutama pajak reklame.
Berikut akan dikemukakan pendapat responden tentang pengaruh kebijakan ekonomi dan moneter terhadap realisasi pajak reklame dalam tabel 18 sebagai berikut:

Tabel 21

Tanggapan Responden Terhadap Pengaruh Kebijakan Ekonomi Dan Moneter Terhadap Realisasi Pajak Reklame

\begin{tabular}{|c|c|c|c|}
\hline No. & $\begin{array}{c}\text { Klasifikasi } \\
\text { Jawaban }\end{array}$ & Frekuensi & $\begin{array}{c}\text { Persentase } \\
(\%)\end{array}$ \\
\hline 1 & $\begin{array}{l}\text { Sangat } \\
\text { Setuju }\end{array}$ & 33 & 89,2 \\
\hline 2 & Setuju & 4 & 10,8 \\
\hline 3 & $\begin{array}{l}\text { Kurang } \\
\text { Setuju }\end{array}$ & 0 & 0 \\
\hline 4 & $\begin{array}{l}\text { Tidak } \\
\text { Setuju }\end{array}$ & 0 & 0 \\
\hline 5 & $\begin{array}{l}\text { Sangat } \\
\text { Tidak } \\
\text { Setuju }\end{array}$ & 0 & 0 \\
\hline \multicolumn{2}{|r|}{ Total } & 37 & 100 \\
\hline
\end{tabular}

Sumber : Hasil Olahan Data Primer, 2015

Dari tabel di atas menunjukkan bahwa 33 responden yang menjawab sangat setuju atau sebanyak $89,2 \%$ berpendapat bahwa kebijakan ekonomi dan moneter berpengaruh sangat baik terhadap realisasi pajak reklame Kabupaten Donggala dan 4 orang responden yang menjawab setuju atau sebanuak 10,8\% menyatakan baik, Sehingga disimpulkan bahwa pengaruh kebijakan ekonomi dan moneter terhadap realisasi pajak reklame kabupaten Donggala kurang baik. Indikasi tersebut menggambarkan kebijakan ekonomi dan moneter Kabupaten Donggala belum memberikan pengaruh peningkatan keadaan sosial ekonomi masyarakat. Sehingga peningkatan sektor pajak reklame dan kontribusinya sangat rendah.

\section{KESIMPULAN \\ Kesimpulan}

Berdasarkan hasil analisis dan pembahasan yang telah dikemukakan di atas maka penulis dapat menyimpulkan beberapa hal sebagai berikut :

1. Hasil penelitian menunjukkan bahwa implementasi kebijakan Pajak Reklame terhadap peningkatan Pendapatan Asli Daerah pada Dinas Pendapatan, Pengelolaan Keuangan dan Asset Daerah Kabupaten 


\section{Iumal ERonomi Trend Vol. 07 TNo. 02 Jufi-Desember 2019 E-ISSN. 2722-6565}

Donggala yang terdiri dari empat indikator yaitu komunikasi (communication), Sumbersumber (resources), dampak (dispositions) dan Birokrasi (bureaucratic). Dari keempat indikator tersebut masih ada sub indikator yang masih perlu ditingkatkan yaitu sub indikator sarana dan prasarana, pelaksana kebijakan, perilaku pembuat kebijakan, dan kesesuaian pelayanan, namun secara akumulatif responden memberikan tanggapan efektif atau baik.

2. Realisasi pajak reklame dari tahun ke tahun menunjukkan peningkatan dimana pada tahun 2012 dan 2013 relisasi pajak reklame dapat melampai target walaupu $\mathrm{n}$ persentasi pencapaiannya menurun pada tahun 2012 sebesar $126,7 \%$ menjadi $104 \%$ pada tahun 2013.

3. Kontribusi pajak reklame terhadap Pendapatan Asli Daerah Kabupaten Donggala masih sangat kurang dengan nilai kontribusi pada tahun 2011 hingga 2013 hanya berkisar ratarata $0.3 \%$ dari PAD. Ini menunjukkan sektor usaha produktif rakyat tidak berkembang sehingga kegiatan promosi dengan pemasangan reklame rendah

4 Faktor yang mempengaruhi terhadap realisasi pajak reklame Pendapatan Asli Daerah Pada Dinas Pendapatan Daerah Kabupaten Donggala dapat dijelaskan yaitu : Faktor penghambat dan pendukung realisasi tahun sebelumnya, Pencairah Tagihan Tahun Sebelumnya, Data Potensi dan Estimasi, Penyesuain tarif dan penyempurnaan system pungutan masih perlu ditingkatkan dan menjaadi perhatian bagi implementator. Sedangkan faktor Keadaan Sosial-ekonomi dan kesadaran wajib pajak dan Kebijakan ekonomi dan moneter harus menjadi perhatian khusus Pemerintah Daerah Kabupaten Donggala karena besar kecilnya penerimaan daerah tergantung keadaan ekonomi dan sosial masyarakat maka perlu ada kebijakan kebijakan ekonomi yang dapat meningkatkan taraf ekonomi dan sosial masyarakat Kabupaten Donggala.

\section{Saran}

Untuk lebih meningkatkan kualitas pelayanan, maka peneliti menyarankan beberapa hal sebagai berikut :

1. Dalam upaya peningkatan PAD khususnya dari pajak reklame, hendaknya lebih meningkatkan penuluhan dan sosialisasi kepada masyarakat akan pentingnya arti pajak dalam pembangunan, sehingga masyarakat menyadari dan membayar pajak sesuai dengan waktu yang telah ditentukan.

2. Hendaknya pimpinan sebagai pengambil kebijakan, memberikan kesempatan bagi setiap pegawai negeri sipil, khususnya staf bendaharawan untuk mengikuti latihan/kursus-kursus yang berhubungan dengan tugasnya.

Sarana dan prasarana sebagai pendukung dalam penyajian data yang akurat untuk mendukung laporan pertanggung jawaban pada atasan, hendaknya pelu ditingkatkan dan merupakan prioritas utama. 


\section{DAFTAR PUSTAKA}

Abdul Wahab, Solichin. 2001. Analisis Kebijakan Negara, Rhineka Cipta. Jakarta.

Anderson, James E. 1979, Public Policy-Making, Holt, Rinehart and Winston: New York.

Arikuto, Suharsimi. 1996. Prosedur Penelitian Suatu Pendekatan Praktek Rhineka Cipta, Jakarta

Black dan Champion, 2001. Penelitian Sosial (Metode dan masalah), Rieka Aditama, Jakarta.

Dunn, W.N. 1995. Analisa Kebijaksanaan Publik. PT. Hanindita Garaha Widya, Yogyakarta.

Dunn, W.N,2000. Pengantar Analisis Kebijakan PublikEdisi Kedua (terjemahan Samodra Wibawa, Diah Asitadani, Erwan Agus Purwanto).Gajah mada University Press: Yogyakarta.

Dunn, W.N, 2001. Analisis Kebijakan Publik, Hanindita Graha Widya, Yogyakarta.

Darwin Muhajir, 1993. Implementai Kebijakan. Makalah. UGM Yogyakarta.

Edward III, 1980. Implementing Public Policy. Congressional Quartely Press. Washinton DC.

Faisal, Sanapiah. 2001. Format-Format Penelitian Sosial, PT. Raja Grafindo Persada: Jakarta.

Gaffar, H. Affan. 1995, Policy Prosess and Formulation (modul 1), Universitas 17 Agustus 1945, Surabaya.

Guritno, T. 1997. Kamus Ekonomi-binis-perbankan : InggrisIndonesia. Gajah Mada University Press. Yogyakarta.

Hamdi, Mukhlis. 1999. Desentralisasi dan Pembangunan Daerah.Makalahpadalokakarya Kemampuan Pemda TK II: Jakarta

Irwansyah, 2014. efektivitas dan kontribusi pajak hotel terhadap pendapatan asli daerah (Studi di Pemerintah Daerah Kota Semarang). Universitas Diponegoro, Semarang.

Islamy Irfan, 2008. Prinsip Prinsip Rumusan Kebijaksanaan Negara. Bumi Aksara. Jakarta.

Kurniawan, Dhani,. 2011, Kontribusi pajak reklame terhadap pendapatan asli daerah Kabupaten Kudus, Universitas Muria Kudus : Kudus.

Lembaga Adminsistrasi Negara. 1993, Pengernbangan Pelaksanaan Pelayanan Prima, Bahan Ajaran Diklatpirn Tingkat 1/1, STIA-LAN Press, Jakarta.

Ludgardia Budiningsih, Martoyo, Isdairi. 2013. Kebijakan Pemungutan Pajak Reklame Berdasarkan Peraturan Daerah (perda) no. 2 Tahun 2011
Tentang Pajak Daerah di Kabupaten Sintang. UNTAN, Pontianak

Masri Singarimbun dan Sofyan Efendi. 2007. Metode Penelitian Survey. LP3ES. Jakarta

Singarimbun Masri dan Sofian Effendi. 1997. Metode Penelitian Survey. PT Pustaka LP3ES Indonesia: Jakarta

Penelitian Survey. LP3ES. Jakarta.

Midiyati, Meilyna Nur, 2013. Analisis Efektivitas Dan Efisiensi Pemungutan Pajak Reklame Serta Kontribusinya Terhadap Penerimaan Pajak Daerah (Studi Kasus Pada Dpkad Kota Semarang), Jurnal Ekonomi dan Bisnis, Universitas Dian Nuswantoro : Semarang.

Meter, Donald Van, dan Carl Van Horn, 1975, " The Policy Implementation Process: A Conceptual Framework dalam Administration and Society 6, 1975, Sage: London.

Moeljono, Djokosantoso. 2006. Cultured! Budaya Organisasi dalam Tantangan. PT. Elex Media Komputindo: Jakarta.

Mulyasa, 2005. Implementasi Kurikulum 2004. Panduan Pembelajaran KBK. Remaja Rosdakarya. Jakarta.

Mustopadidjaja. 2001. Reformasi Birokrasi, Perwujudan Good Governance, dan Pembangunan Masyarakat Madani, Makalah disampaikan pada Silaknas ICMI 2001, Jakarta.

Nugroho, Riant. 2003. KEBIJAKAN PUBLIK Formulasi, Implementasi, dan Evaluasi, Elex Media: Jakarta Komputindo.

Nugroho, Rian, 2006. Kebijakan Publik untuk Negara Berkembang (Modul-modul Perumusan Implementasi dan Evaluasi) Gramedia. Jakarta.

Nasir. M.safar, 2003. Pengukuran Kinerja Pemerintah Daerah. UAD Press, Yogyakarta.

Subarsono,. 2005. Analisa Kebijakan Publik. Pustaka Pelajar, Yogyakarta.

Rahman, A. (2019). Pengaruh Hubungan Interpersonal, Lingkungan Kerja, Dan Kecerdasan Emosional Terhadap Kinerja Pegawai Pada Kantor Komisi Pemilihan Umum Daerah (Kpud) Kabupaten Parigi Moutong. Jurnal Ekonomi Trend, 7(1), 58-70. Https://Doi.Org/10.31970/Trend.V7i1.173

Sugiyono, 1993. Metode Penelitian Administrasi Negara, Alfabeta, Bandung

2003. Statistik Untuk Penelitian,Cetakan Kelima, Alfabeta, Bandung

2006. Metode Penelitian Administrasi Negara, Alfabeta, Bandung

Suparmoko M, 2002,Azas-azas Ilmu Keuangan Negara Edisi Kedua,BPFE,Yogyakarta. 
Sutrisno Hadi. 1997. Metode Research. Yayasan Penerbit Fakultas Fisiologi UGM: Yogyakarta.

Udoji, Chief, 2009. The African Public Servant as A Public Policy in African Association for Public Administration and Management. Addis Adeba.

Undang - undang No. 32 tahun 2004 tentang Otonomi Daerah, www.esdm.go.id

Undang - undang No. 34 tahun 2004 tentang Pajak Daerah, www.depkeu.go.id

Velayati, M Rizkika, Dkk. 2013. Analisis efektivitas dan kontribusi tindakan penagihan pajak aktif dengan surat teguran dan surat paksa sebagai upaya pencairan tunggakan pajak. Studi pada kantor pelayanan pajak pratama batu tahun 2010-2012. Universitas Brawijaya. Skripsi, Malang

Wahyuni, Sri. 2011. Implementasi Kebijakan Pajak Reklame Untuk Meningkatkan Pendapatan Asli Daerah (PAD) Kota Malang, Skripsi, Universitas Negeri Malang : Malang

Wibowo, 1994. Manajemen Kinerja, Raja Grafindo Persada. Jakarta.

Wibawa, Samodra. Dkk. 1994. Evaluasi Kebijakan Publik. Raja Grafindo Persada, Jakarta.

Widodo, Suseno Triyanto., 1990, Indikator Ekonomi, Kanisius, Yogyakarta.

Widodo, 2001. Good Governance, Telaah dari Dimensi dan Kontrol Birokrasi pada Era Desentralisasi dan Otonomi Daerah, Insan Cendikia, Bandung.

Winarno, 2002. Teori dan Proses Kebijakan Publik, Media Pressindo, Yogyakarta.

Yanes Charles, 1991. Pengantar Kebijakan Publik. Rajawali Press. Jakarta. 